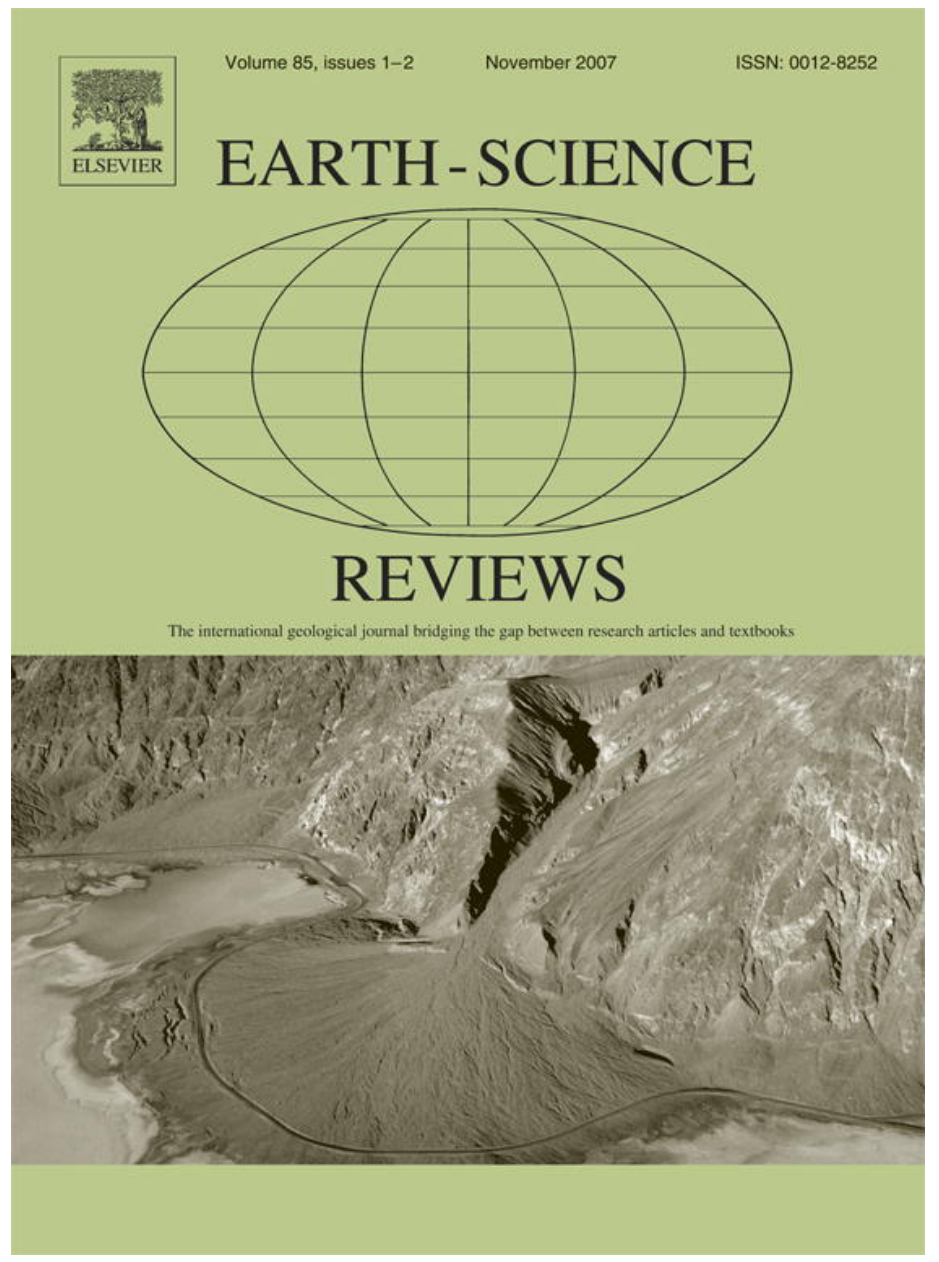

This article was published in an Elsevier journal. The attached copy

is furnished to the author for non-commercial research and education use, including for instruction at the author's institution, sharing with colleagues and providing to institution administration.

Other uses, including reproduction and distribution, or selling or licensing copies, or posting to personal, institutional or third party websites are prohibited.

In most cases authors are permitted to post their version of the article (e.g. in Word or Tex form) to their personal website or institutional repository. Authors requiring further information regarding Elsevier's archiving and manuscript policies are encouraged to visit: 


\title{
A review of the Late Cambrian (Furongian) palaeogeography in the western Mediterranean region, NW Gondwana
}

\author{
J. Javier Álvaro ${ }^{\mathrm{a}, \mathrm{b}, *}$, Annalisa Ferretti ${ }^{\mathrm{c}}$, Cristina González-Gómez ${ }^{\mathrm{a}}$, Enrico Serpagli ${ }^{\mathrm{d}}$, \\ M. Franco Tortello ${ }^{\mathrm{e}}$, Marco Vecoli ${ }^{\mathrm{b}}$, Daniel Vizcaïno ${ }^{\mathrm{f}}$ \\ ${ }^{a}$ Departamento Ciencias de la Tierra, Universidad de Zaragoza, 50009-Zaragoza, Spain \\ b Laboratoire 'Paléontologie et Paléogéographie du Paléozö̈que', UMR 8014 CNRS, Université de Lille I, 59655-Villeneuve d'Ascq, France \\ ${ }^{\mathrm{c}}$ Dipartimento di Scienze della Terra, Università di Modena e Reggio Emilia, largo S. Eufemia 19, 41100-Modena, Italy \\ ${ }^{\mathrm{d}}$ Dipartimento del Museo di Paleobiologia e dell'Orto Botanico, Università di Modena e Reggio Emilia, Via Università 4, 41100-Modena, Italy

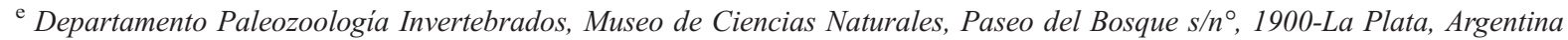 \\ ${ }^{\mathrm{f}} 7$ rue Jean-Baptiste Chardin, Maquens, 11090-Carcassonne, France
}

Received 18 December 2006; accepted 25 June 2007

Available online 6 August 2007

\begin{abstract}
The Cambrian-Ordovician transition of the western Mediterranean region (NW Gondwana) is characterized by the record of major erosive unconformities with gaps that range from a chronostratigraphic stage to a series. The hiatii are diachronous and involved progressively younger strata along the Gondwanan margin, from SW (Morocco) to NE (Montagne Noire). They can be related to development of a multi-stage rifting (further North), currently connected to the opening of the Rheic Ocean, and concomitant erosion on southern rift shoulders. The platforms of this margin of Gondwana occupied temperate-water, mid latitudes and were dominated by siliciclastic sedimentation, while carbonate factories were only episodically active in the Montagne-Noire platform.

The Upper Cambrian is devoid of significant gaps in the southern Montagne Noire and the Iberian Chains. There, the sedimentation took place in a transgressive-dominated depositional system, with common offshore deposits and clayey substrates, and was bracketed by two major regressive trends. The Late Cambrian is also associated with the record of volcanic activity (e.g., in the Cantabrian and Ossa-Morena zones, and the northern Montagne Noire), and widespread development of a tectonic instability that led to the episodic establishment of palaeotopographies and record of slope-related facies associations.

Several immigration events are recognized throughout the latest Middle Cambrian, Late Cambrian and Tremadocian. The trilobites show a stepwise replacement of Acado-Baltic-type families (e.g., the conocoryphid-paradoxidid-solenopleurid assemblage) characterized by: (i) a late Languedocian (latest Middle Cambrian) co-occurrence of Middle Cambrian trilobite families with the first anomocarid, dorypygid and proasaphiscid invaders; (ii) a Late Cambrian immigration replacing previous faunas, composed of trilobites (aphelaspidids, catillicephalids, ceratopygids, damesellids, eulomids, idahoiids, linchakephalids, lisariids, onchonotinids, and pagodiids), linguliformean brachiopods (acrotretids, obolids, scaphelasmatids, siphonotretids, and zhanatellids), echinoderms (mitrates, glyptocystitid cystoids, and stromatocystoids), and conodonts belonging to the lower Peltura Zone; and (iii) the subsequent input of new trilobites (asaphids, calymenids, catillicephalids, nileids and remopleurids), which
\end{abstract}

\footnotetext{
* Corresponding author. Departamento Ciencias de la Tierra, Universidad de Zaragoza, 50009-Zaragoza, Spain.

E-mail addresses: Jose-Javier.Alvaro@univ-lille1.fr (J.J. Álvaro), ferretti@unimore.it (A. Ferretti), cgonzale@unizar.es (C. González-Gómez), serpagli@unimore.it (E. Serpagli), tortello@museo.fcnym.unlp.edu.ar (M.F. Tortello), Marco.Vecoli@univ-lille1.fr (M. Vecoli), daniel.vizcaino@wanadoo.fr (D. Vizcaïno).
} 
marks the base of the Proteuloma geinitzi Zone, associated with pelmatozoan holdfasts (Oryctoconus), and a distinct input of late Tremadocian conodonts (Paltodus deltifer Zone).

The biogeographic distribution of latest Middle and Late Cambrian trilobites supports brachiopod data indicating strong affinities between the western Mediterranean region, East Gondwana (North China/Korea, South China, Australia, and Antarctica) and Kazakhstania during the late Languedocian, which became significantly stronger during the Late Cambrian. This major shift may suggest modification in oceanic circulation patterns throughout Gondwana across the Middle-Late Cambrian transition. (C) 2007 Elsevier B.V. All rights reserved.

Keywords: Late Cambrian; stratigraphy; palaeoenvironments; palaeogeography; palaeobiogeography; trilobites; brachiopods; echinoderms; events; Morocco; SW Europe; Rheic Ocean; Gondwana

\section{Introduction}

The geological setting of Late Cambrian sedimentary basins bordering NW Gondwana reflects the presence of extensive shallow-water intra- and epicratonic seas. The identification of Late Cambrian fossils and correlation of their respective strata throughout the western Mediterranean region (herewith applied to Morocco, the Iberian Peninsula, France and Sardinia) have been currently constrained by the abundance of stratigraphic gaps, condensed strata and scarcity of shelly fossils, many of which are exclusively endemic and unavailable for intercontinental correlation, as well as by the paucity of calcareous levels suitable for conodont investigation. There, the Late Cambrian represents a transitional time span between: (i) rifting processes recorded across the Neoproterozoic-Cambrian transition in Ossa-Morena (southern Iberian Peninsula; Sánchez-García et al., 2003) and Morocco (Gasquet et al., 2005); and (ii) a succession of magmatic episodes and tectonic perturbations that precluded the opening of the Rheic Ocean. This was the result of the drift of peri-Gondwanan terranes, such as Avalonia and Carolina from West Gondwana (see, e.g., Prigmore et al., 1997; Stampfli et al., 2002; Murphy et al., 2006; but see Landing, 2005, for another point of view). Upper Cambrian strata of the western Gondwanan margin also recorded a major palaeoclimatic influence related to its southward drift that led to a gradual cooling of waters, grading from Early Cambrian subtropical to Late Ordovician subpolar settings (Álvaro et al., 2000, 2003a), and a distinct immigration of East Gondwanan invaders that reached its peak during the late Languedocian (latest Middle Cambrian) and Late Cambrian (Courtessole et al., 1988; Álvaro et al., 1999; Shergold et al., 2000).

The aim of this paper is to document the sedimentary response recorded in NW Gondwana to the opening of the Rheic Ocean and the southward drift into temperate waters during the Late Cambrian. For this, we offer an integrated stratigraphic framework of the Upper Cam- brian from the western Mediterranean region, based on litho-, bio-, and ecostratigraphic analyses, sequenceand event-stratigraphic approaches, and reconstruction of benthic community replacements. We are confident that this work might be of some help to overcome the difficulties to apply the recently erected Furongian Series in this margin of Gondwana.

\section{The Furongian Series}

Numerous regional chronostratigraphic subdivisions of the Upper Cambrian have been traditionally used all over the world (e.g., Shergold, 1982; Rushton, 1983; Ludvigsen and Westrop, 1985; Zhang and Jell, 1987; Chang, 1988; Ergaliev, 1990; Palmer, 1998; Geyer and Shergold, 2000; Peng and Robison, 2000; Peng et al., 2001a; Peng and Babcock, 2001; Ahlberg, 2003). Recently, the International Subcommission on Cambrian Stratigraphy selected for the base of a new globally applicable Upper Cambrian Series boundary (named the Furongian Series) the base of the Glyptagnostus reticulatus Zone (Shergold and Geyer, 2001).

The agnostoid trilobite G. reticulatus has one of the broadest palaeobiogeographic distributions of any Cambrian trilobite. It has been identified in Antarctica, Argentina, Australia, Canada, China, Denmark, Kazakhstan, Norway, Russia, South Korea, Sweden, UK, and USA. G. reticulatus is used as a zonal guide fossil in Australia, Kazakhstan, Laurentia, Siberia, and South China (Geyer and Shergold, 2000; Peng and Robison, 2000). Co-occurrences with other agnostoid and polimeroid trilobites allow correlation with Argentina (lower Aphelaspis Zone/lower G. reticulatus Zone-equivalent; Shergold et al., 1995) and Baltica (Homagnostus obesus Zone; Ahlberg, 1998). In addition, the combination of cosmopolitan agnostoids, Gondwanan shelf-dwelling polymeroids, cosmopolitan tropical polymeroids, and other polymeroids from the Jiangnan Slope Belt, where the Furongian was formally defined (Peng et al., 2001b), allows an useful 
correlation of the base of the G. reticulatus Zone with other Gondwanan sectors, such as the North China Platform (Zhang and Jell, 1987), Kazakhstan (Ergaliev, 1990), Australia (Jago and Brown, 1992), Oman (Fortey, 1994), Antarctica (Cooper et al., 1996), and Iran (Peng et al., 1999).

Unfortunately, the absence of $G$. reticulatus and other coeval trilobites in other areas of Gondwana hampers any possible correlation of the newly erected Furongian Series with other 'Upper Cambrian' strata. This is especially dramatic in some temperate- to coldwater platforms, where carbonate strata are scarce or absent, and other biostratigraphically significant taxa, such as conodonts, are not reported: e.g., the base of the Westergaardodina proligula (conodont) Zone occurs slightly below the base of the G. reticulatus Zone (Dong and Bergström, 2001), and may be used as a key chronostratigraphic marker. Even the identification of the Cambrian-Ordovician (or Furongian-Tremadocian) boundary reflects the same problem. The Cambrian-Ordovician Boundary Working Group selected in 1998 as the base of the Ordovician the base of the Iapetognathus fluctivagus (conodont) Zone, which approximates the Cordylodus lindstromi Zone, the Rhabdinopora flabelliforme Zone and the first appearance (FAD) of the trilobite Jujuyaspis. The GSSP for this boundary was chosen at the Green Point section, Newfoundland (Cooper and Nowlan, 1999), but its identification in siliciclastic platforms is problematical.

Another tool for correlation of the base of the Furongian is chemostratigraphy. The base of the G. reticulatus Zone closely corresponds with the onset of a large positive shift in $\delta^{13} \mathrm{C}$ values referred to as the Steptoean Positive Carbon Isotope Excursion (or SPICE excursion; Brasier, 1993; Saltzman et al., 1998). The SPICE excursion reaches peak values of about $+4 \%$ $\delta^{13} \mathrm{C}$ between the FAD of G. reticulatus and the FAD of Irvingella (Saltzman et al., 2000), at a position roughly corresponding to the interval of maximum biotic diversity in the Pterocephaliid Biomere of Laurentia (Rowell and Brady, 1976). The excursion has been documented from sections in Paibi and Wa'ergang (South China), the Kyrshabakty river section and Malayi Karatau (Kazakhstan), Queensland (Australia), and the Great Basin (USA). Carbonate environments yielding the SPICE excursion range from slopes where dark, thin-bedded limestones predominate, to shallow platforms where a variety of carbonate lithofacies (boundstones, ooidal grainstones, and fenestral limestones) are present (Saltzman et al., 2000). A rise in seawater ${ }^{87} \mathrm{Sr} /{ }^{86} \mathrm{Sr}$ values, coinciding with the SPICE excursion, has also been documented in Laurentia
(Montañez et al., 1996; Denison et al., 1998), and presumably has global significance.

The Furongian is bracketed between several confident radiometric dates: a latest Middle Cambrian age $(\mathrm{U}-\mathrm{Pb}$ zircon age of $505.1 \pm 1.3 \mathrm{Ma}$ ) yielded by ignimbrites from the Taylor Formation (a probable equivalent of the Floran/Undillan, Antarctica; Encarnacion et al., 1999), and a latest Late Cambrian age (U-Pb zircon age of $491 \pm 1 \mathrm{Ma}$ ) reported from an ash bed located close to the top of the Upper Cambrian in North Wales (Davidek et al., 1998), and two thin volcanoclastic sandstone beds overlain by Rhabdinopora debris in North Wales that have yielded an $\mathrm{U}-\mathrm{Pb}$ zircon age of $489 \pm 0.6 \mathrm{Ma}$ (Landing et al., 2000).

\section{The Upper Cambrian Series in the western Mediterranean region}

Traditionally, the taxa used for the identification of the Late Cambrian in the western Mediterranean region have been ichnofossils and acritarchs. Scattered and probably storm-induced coquinas rich in trilobites, echinoderms and brachiopods may be only used for regional correlation. Due to the strong endemism of these taxa, intercontinental correlation has only been tentatively advanced based on shared genera.

In this section, an integrated stratigraphic information of the Upper Cambrian from the Demanda Sierra, the Iberian Chains, the Cantabrian Mountains (Spain), Sardinia (Italy), the southern Montagne Noire (France), and Morocco and neighbouring areas (Fig. 1) is updated and completed with new data. Although the respective degree of knowledge of these areas is heterogeneous (e.g., related to sequence and event stratigraphy), the following description will enable a comparative analysis of relative sea-level fluctuations and events that, in some cases, are shared by all the platforms (Fig. 2).

\subsection{The Demanda Sierra (NE Spain)}

The occurrence of Late Cambrian trilobites in the western Mediterranean region was reported, for the first time, by Colchen $(1967,1974)$ in the Demanda Sierra. $\mathrm{He}$ determined the presence of Chuangia and Prochuangia in the lower member of the Najerilla Formation (Fig. 3). New collections from the same sections were subsequently described and revised by Shergold et al. (1983), who recognized two fossil associations: (i) the oldest comprises four trilobite taxa (aphelaspidine, leiostegiid?, Maladioidella colcheni, and Langyashania felixi), associated with the brachiopod Billingsella cf. lingulaeformis (Colchen and Havlíček, 1968); and 


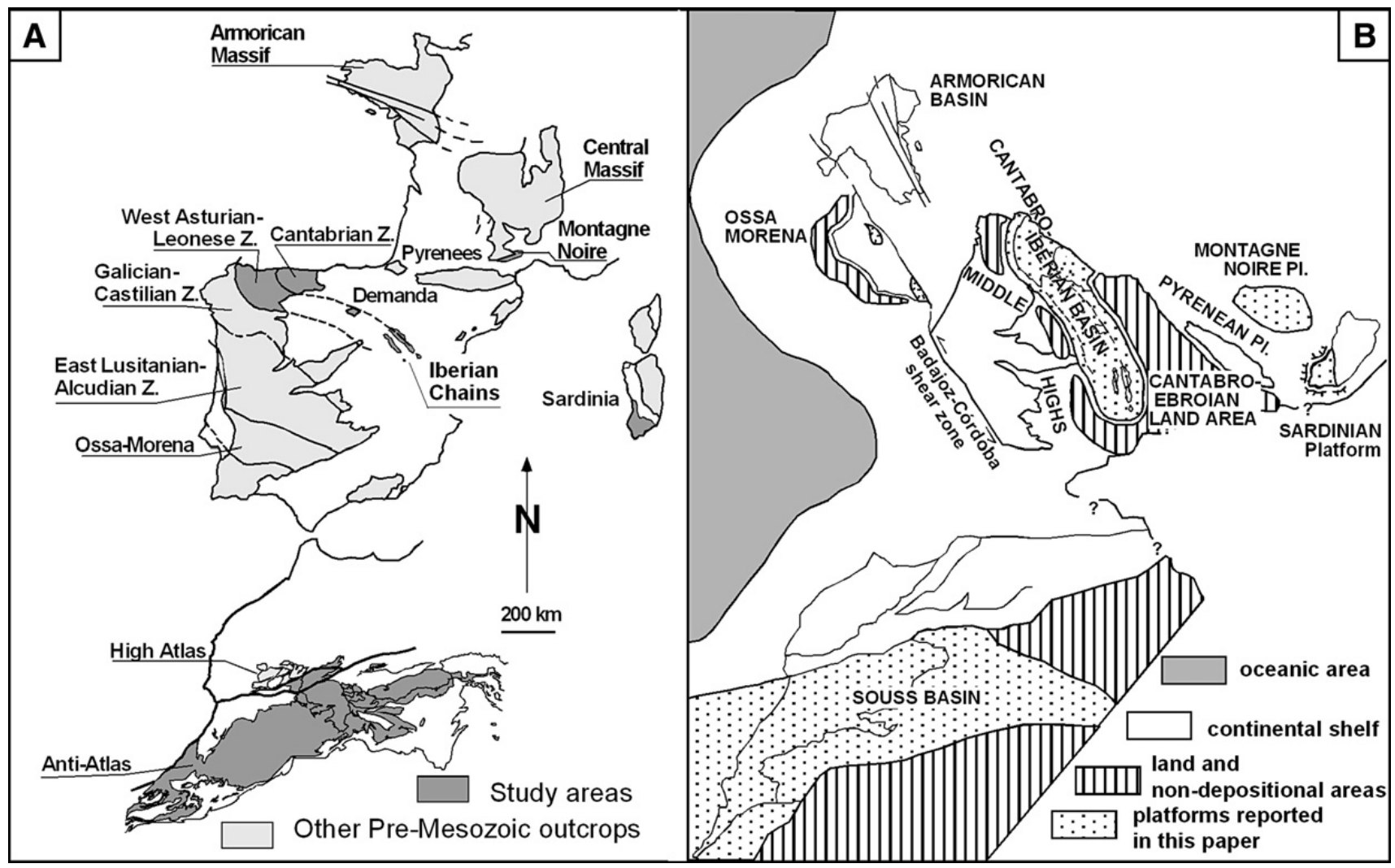

Fig. 1. Location of the Demanda Sierra, the Iberian Chains, the Cantabrian Zone (northern Spain), the Montagne Noire (southern France), Sardinia (Italy) and the Moroccan Anti-Atlas in the pre-Hercynian outcrops of the western Mediterranean region.

(ii) the younger assemblage, from the second member of the Najerilla Formation, contains only two trilobite taxa (pagodiine and a solenopleuroidean? aff. Lajishanaspis) that co-occur with the pelmatozoan holdfast Oryctoconus lobatus (Colchen and Ubaghs, 1969).

A sedimentological and sequence analysis is here reported from the western bank of the Urbión river (Fig. 4), the paratype of the Najerilla Formation, where the aforementioned fossil associations can be found. The Najerilla Formation was subdivided by Colchen (1974) into three members. The lower member, ca. $100 \mathrm{~m}$ thick, is dominated in the study section by brownish shales although some scattered centimetrethick sandstone interbeds and limestone nodules and layers occur. The calcareous layers are partly to wholly limonitized, and have yielded the aforementioned oldest fossil association. The intermediate member, ca. $500 \mathrm{~m}$ thick, consists of alternating sandstones and blue-grey shales, also bearing limonitized limestone nodules, and has produced, at the top, the younger fossil assemblage. The upper member has not yielded shelly fossils, is up to $300 \mathrm{~m}$ thick, and consists of amalgamated sandstone channels and beds with subordinate shale interbeds.
The lower member of the Najerilla Formation displays silty layers, local symmetric ripples, parallel and lowangle lamination, and coquinas with erosive bases and grading. No distinct parasequences (or 4th order sequences) are visible, and the sedimentary structures and fossil disarticulation suggest deposition under calm conditions episodically interrupted by waves and storms, in an offshore-dominated setting. A progressive regressive trend is recognized upsection, due to development of coarsening- and thickening-upward parasequences, 1.2 to $4.8 \mathrm{~m}$ thick. Parasequences display a vertical succession from: (i) homogeneous shales bearing isolated bioclastic limestone nodules and local slumps; to (ii) thin- to thickbedded sandstone bodies, with an upward change from tabular to lenticular sets that grade from medium- to largescale, trough cross-bedding and wave-ripple lamination; some erosive bases are covered by lagged channels, in some cases lined by brachiopod-rich coquinas; and (iii) centimetre-thick sandstone/shale rhythmites with parallel and low-angle lamination, flaser-to-lenticular structures and, locally, centimetre-thick, sandstone channels with polymodal palaeocurrents. Each parasequence represents shoaling processes with progradation from open-sea offshore to shoal complex and back-shoal, 


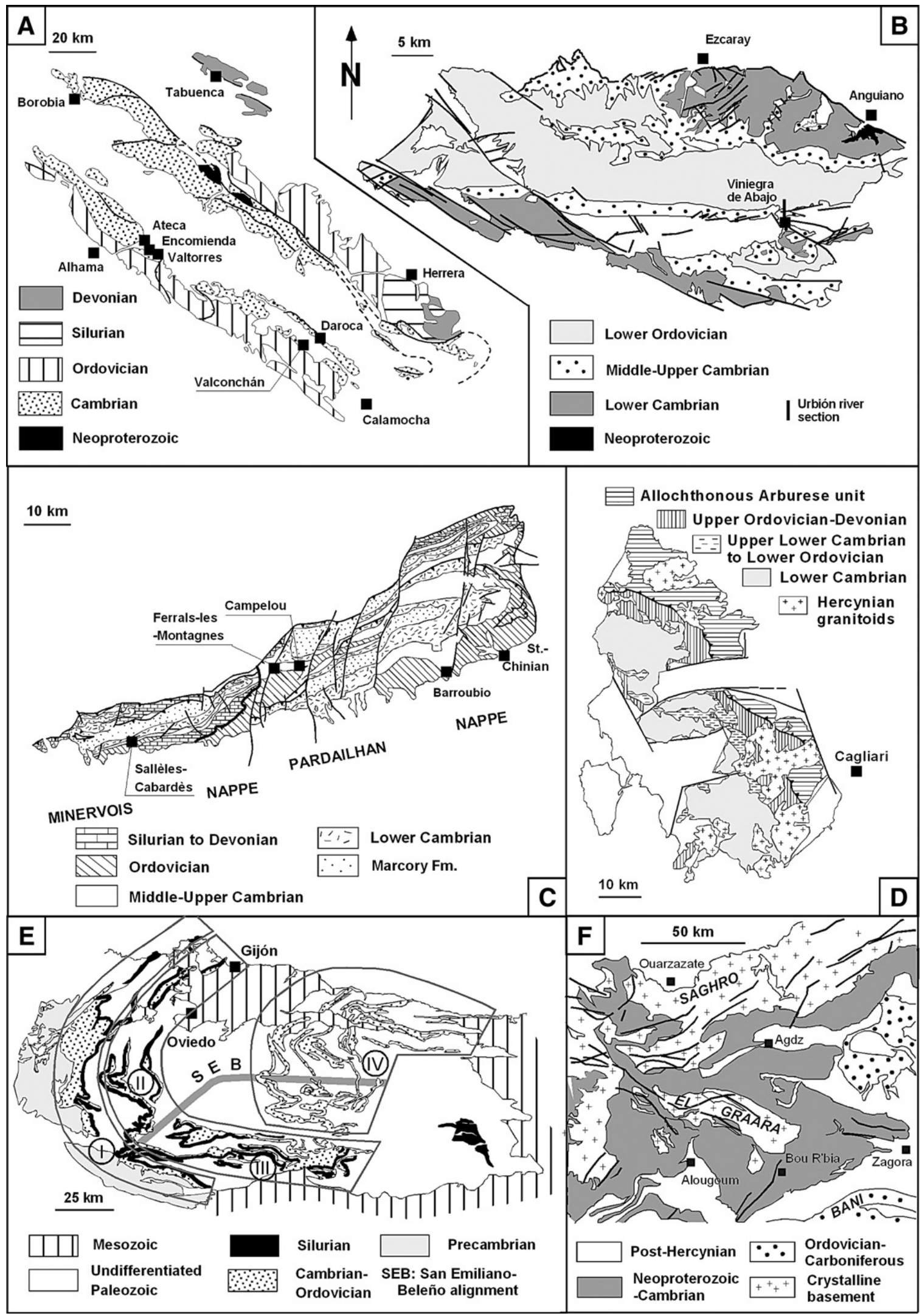

Fig. 2. Geological maps of the pre-Hercynian outcrops of (A) the Iberian Chains, (B) the Demanda Sierra, (C) the Minervois and Pardailhan nappes of the southern Montagne Noire, (D) SW Sardinia, (E) the Cantabrian Zone, and (F) the El Graara massif (Anti-Atlas), with setting of stratigraphic logs reported in the text. 


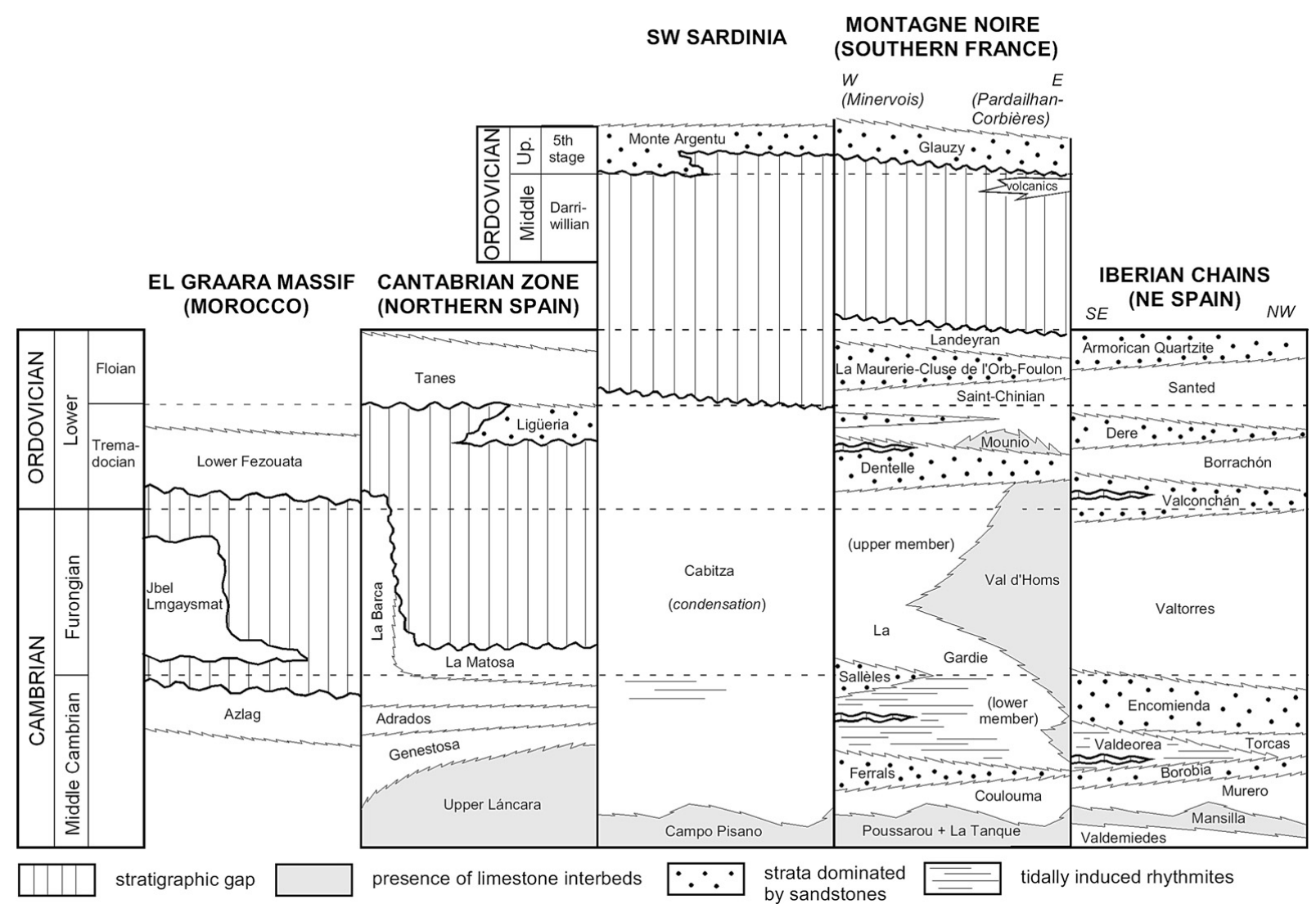

Fig. 3. Sketch illustrating the Upper Cambrian stratigraphic units and their related stratigraphic gaps from the western Mediterranean region, based on papers reported in this paper and new data. 
probably tidally influenced, depositional systems. As a result, the Cambrian-Ordovician transition of the Urbión river section has recorded a global regressive trend recorded in a siliciclastic rimmed platform with episodic colonization of trilobites and echinoderms in distal, opensea, offshore clayey substrates. The regressive trend is capped by an erosive discontinuity that marks the base of the upper member of the Najerilla Formation, and the subsequent amalgamation of nearshore (continental?) coarse-grained sandstones.

\subsection{The Iberian Chains (NE Spain)}

The upper Middle Cambrian to Tremadocian strata of the Iberian Chains are characterized by a thick and conformable succession of exclusively siliciclastic sediments. These strata were originally grouped into an informal 'Iberian Series' (Schmitz, 1971; Josopait, 1972; Shergold and Sdzuy, 1991). This unit was subsequently revised by Álvaro (1995), who subdivided the Acón Group (or 'Iberian Series') into the Borobia, Valdeorea, Torcas, Encomienda, and Valtorres formations. Upper Cambrian strata are broadly distributed across the Encomienda, Valtorres (Acón Group) and Valconchán (Ateca Group) formations (Fig. 4), although acritarchs from the underlying Torcas Formation may suggest a Late Cambrian age (Palacios, 1997). The Encomienda Formation, 150-200 m thick, is dominated by sandstones and quartzites interbedded with subordinate shales. The Valtorres Formation is mainly represented by more than $300 \mathrm{~m}$ of shales with isolated sandstone intercalations. The Valconchán Formation, 30-400 $\mathrm{m}$ thick, consists of sandstones and quartzites with thin intercalations of shales and conglomeratic lenses, the latter becoming significant toward the top of the formation (Wolf, 1980; Álvaro, 1995).

The identification of the Late Cambrian in the Iberian Chains is dramatically constrained by the scarcity of biostratigraphically significant markers within the fossil assemblage, which is dominated by trilobites, brachiopods, acritarchs and ichnofossils (Schmitz, 1971; Josopait, 1972; Havlíček and Josopait, 1972; Kolb and Wolf, 1979; Shergold and Sdzuy, 1991; Álvaro, 1995). The youngest Middle Cambrian trilobites of the Iberian Chains (represented by Solenopleura s.1.) are situated in the lower part of the Encomienda Formation. This taxon is associated with some pelmatozoan ossicles, the hyolith Ortotheca, and the linguliformean brachiopods Lingulella sp., Obolus sp., Obolidae spp., Westonia aff. iphis, and Westonia sp. The upper part of the Encomienda Formation has yielded an impoverished brachiopod assemblage composed of Obolus sp. and Westonia cf. iphis.

Trilobites re-appear in the middle part of the overlying Valtorres Formation and in the lowermost part of the Valconchán Formation (Wolf, 1980; Shergold and Sdzuy, 1991; Álvaro, 1995). They form a Late Cambrian association, determined for the first time by Sdzuy (in Josopait, 1972), and subsequently described by Shergold and Sdzuy (1991). This faunal association includes agnostoid, aphelaspidine aff. Aphelaspis rara (Orłowski) sensu Żylińska (2001), Elegantaspis cf. beta, Parachangshania? sp., Pseudagnostus sp., Punctaspis? schmitzi, solenopleuroidean, and Valtorresia volkeri, associated with the brachiopods Billingsella jalonensis, B. cf. jalonensis, and B. perarea. According to Shergold and Sdzuy (1991), this fauna can be considered as probably early Franconian in age (Steptoean, according to the North American chronostratigraphic chart; Palmer, 1998), and approximately related to the Parabolina spinulosa Zone (Baltica).

The uppermost part of the Valconchán Formation has yielded a distinct trilobite association, composed of Pagodia (Wittekindtia) alarbaensis and olenid fragments thought to represent a species of Jujuyaspis that would indicate an early Tremadocian age (Shergold and Sdzuy, 1991; Álvaro et al., 2003a), and the brachiopod Protambonites primigenius. In addition, both here and in the Demanda Sierra, pagodiine trilobites co-occur with the pelmatozoan holdfast $O$. lobatus. The latter is associated in Sardinia with the graptolite Rhabdinopora flabelliformis, the trilobite Proteuloma geinitzi and agediagnostic acritarchs (Álvaro and Colchen, 2002), all of them of distinct early Tremadocian age (Barca et al., 1987; Pillola and Leone, 1993; Loi et al., 1995).

About $75 \%$ of the aggregate thickness of the Encomienda type section (Encomienda valley, western Iberian Chain) is incorporated into shallowing- and coarsening-upward parasequences, which average 5$25 \mathrm{~m}$ in thickness (Álvaro and Vennin, 1996a). From bottom to top, almost all the parasequences display a succession from: (i) massive claystones, poor in benthic fauna, locally interrupted by centimetre-thick, graded silty layers, hummocky structures, and scarce ripple lamination, exhibiting a wide diversity of burrowing traces; (ii) thick-bedded, fine- to medium-grained sandstones exhibiting medium-scale, trough crossbedding and wave-ripple lamination, interrupted by reactivation surfaces lined by clay laminae, and locally covered by lagged erosive channels, composed of intraformational conglomerates and abraded linguliformean brachiopods; and (iii) thin-bedded laminae of sandstone/claystone rhythmites rich in ichnofossils, 
Urbion river,

Demanda Sierra

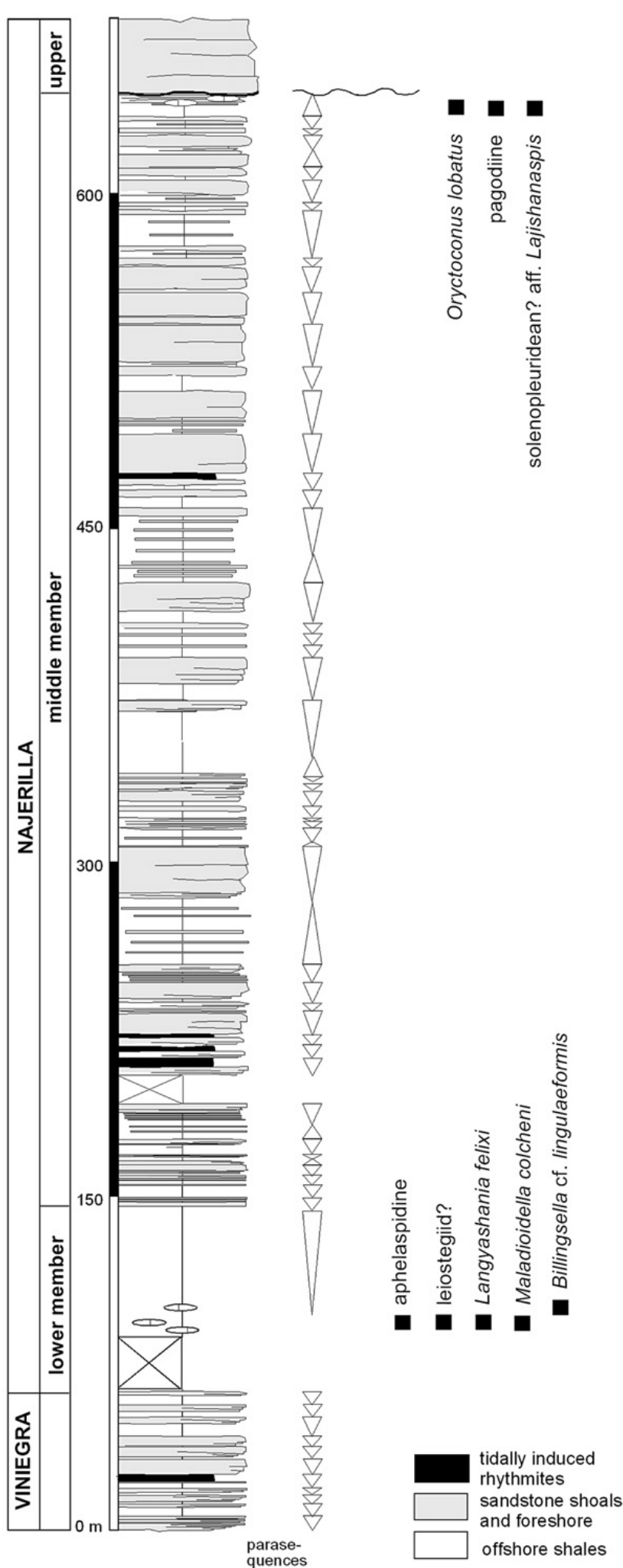

Valconchán type section, Iberian Chains

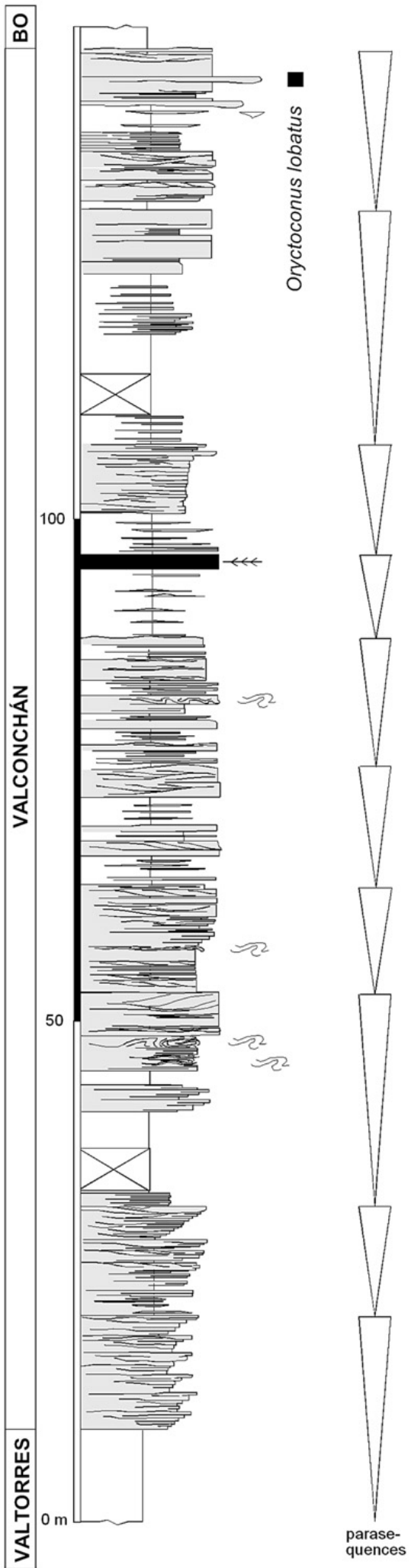

Fig. 4. Facies, fossiliferous levels and sequence-stratigraphic framework of the Cambrian-Ordovician transition from the type sections of the Demanda Sierra (Urbión river) and the Iberian Chains (Valconchán), see legend in Fig. 6. 
flaser-to-lenticular siltstone bedding, and horizontal and low-angle laminae, locally truncated by low-angle reactivation and erosive surfaces overlain by fine-grained sandstone beds. The parasequences display vertically repetitive progradational trends from: (i) offshore to (ii) shoal complexes (shoreface) recording minor storm wash-over channels, and (iii) tidally induced back-shoals dissected by channels.

The overlying Valtorres Formation consists dominantly of homogeneous shales commonly interrupted by storm-induced cycles, $c a .20 \mathrm{~cm}$ in averaged thickness. The formation represents deposition in a low energy outer-platform setting, with only fine-grained terrigenous input and episodic influence of storms (Álvaro and Vennin, 1996a).

The type section of the Valconchán Formation displays shoaling parasequences similar to those described for the middle member of the Najerilla and the Encomienda formations (Fig. 4). Three further features are remarkable: (i) the abundance of slumps and contorted beds at the base of many shoaling parasequences; (ii) the presence of herringbone structures embedded in the tidally induced rhythmites that cap some of the shoaling parasequences; and (iii) the upward increase of channeled conglomerates rich in either Oryctoconus holdfasts or linguliformean brachiopods, the latter forming phosphoarenites. These channels truncate both the base and the upper part of amalgamated shoals, reflecting pulses of increased energy probably winnowing benthic communities that colonized the top of shoals during episodes in which the bars ceased to migrate.

It is remarkable the fact that the Encomienda, Valtorres and Valconchán formations display distinct sloperelated facies associations. Álvaro and Vennin (1996a) described the local presence of decimetre-scale, slumping and sliding strata (underlain by flute, groove and impact marks), unsorted and ungraded blocks and swarms of siltstone and sandstone pillows 'floating' in a shaly matrix. These intraformational blocks and beds were referred to gravity-induced processes related to development of both local slopes and liquefaction and fluidised sediment flow processes, which led the same authors (Álvaro and Vennin, 1996b) to document an interval of episodic tectonic perturbation in the Iberian Chains, broadly restricted to the Late Cambrian.

\subsection{The Cantabrian Mountains (northern Spain)}

In the northern Iberian Peninsula, the foreland fold belt of the Variscan orogen comprises two major tectonostratigraphic units: the Cantabrian Zone, posi- tioned within the inner part of the Asturian or Iberoarmorican arc, and the West Asturian-Leonese Zone (Lotze, 1961). Both 'zones' (a term used here without any biostratigraphic significance) are separated by the Narcea Antiform, the core of which exposes sedimentary Precambrian rocks. We will follow Aramburu (1989) and Aramburu and García-Ramos' (1993) subdivision of the Cantabrian Zone into five palaeogeographic domains, named, from West to East: Narcea Antiform (I), central Asturias (II), northern Leon (III), eastern Asturias (IV), and San Isidro-Tona (V) (Fig. 2).

Identification of the Middle-Upper Cambrian and Upper Cambrian-Tremadocian transitions in the Cantabrian Zone is broadly based on ichnofossils (Seilacher, 1970; Crimes and Marcos, 1976; Baldwin, 1978; Marcos et al., 1982; Legg, 1985), and acritarchs (Fombella, 1986, 1987; Vanguestaine and Aramburu, 1988; Albani et al., 2006). Lag deposits of the pelmatozoan holdfast $O$. lobatus occur in Lower Ordovician quartzarenites at El Horno near Cabo Busto, Cantabrian Zone (Seilacher and MacClintock, 2005), although its stratigraphic setting has not yet been documented in detail.

Three members are involved in the Middle-Upper Cambrian and Upper Cambrian-Tremadocian transitions: the La Barca (Oville Formation), La Matosa and Ligüeria (Barrios Formation) members (Aramburu and García-Ramos, 1993; Fig. 2). The La Barca Member consists of alternating sandstones and shales, bearing scattered glauconite-rich levels, and local volcanic sills and volcanoclastic strata. Its thickness strongly increases from East to West, ranging from 8 to $620 \mathrm{~m}$. The uppermost part of the member is diachronous: it is commonly Middle Cambrian but ranges into Late Cambrian toward NW (Marcos et al., 1982; Vanguestaine and Van Looy, 1983; Legg, 1985). The La Matosa Member, 0-395 $\mathrm{m}$ thick, is dominated by quartzarenite sandstones that change vertically from medium-sorted, very fine-to-fine sandstones with shale interbeds to unsorted, medium-to-coarse-grained sandstones bearing scattered quartzite granules. The member occurs across the whole Cantabrian Zone, except in the northern part of domain I. In domain III, some volcanoclastic levels and a distinct kaolinite-rich bentonite (the so-called Valverdín Bed; García-Ramos et al., 1984) are also documented. The presence of ichnofossils (several ichnospecies of Cruziana; Crimes and Marcos, 1976; Baldwin, 1978) and acritarchs (Vanguestaine and Aramburu, 1988) allows a broad identification of the Upper Cambrian-Tremadocian transition. Finally, the Ligüeria Member, $0-130 \mathrm{~m}$ thick, is underlain by an erosive unconformity, and characterized by a broad 
upward decrease in grain size. The member changes vertically from shale/very fine-grained sandstone alternations, to medium-to-very coarse sandstones bearing upward quartzite-rich conglomerate layers. The erosive unconformity located at the La Matosa/Ligüeria contact, locally scoured and channelled, was firstly related to the Sardic Phase by Aramburu and García-Ramos (1988), although recently Aramburu et al. (2004) have referred it to the Central-Iberian Toledanian unconformity. The overlying conglomerate bed, up to $19 \mathrm{~m}$ thick to the East, contains quartzite granules that can reach $34 \mathrm{~cm}$ in diameter, and shows a northwesternward decrease in grain size and thickness.

The sedimentology of these deposits was studied and successively updated by, among others, Van den Bosch (1969), Gietelink (1973), Baldwin (1977), Legg (1985), Aramburu (1989), Aramburu et al. (1992), and Aramburu and García-Ramos (1993). Although a complete sequence framework is not yet available, the global trend from the La Barca to the Ligüeria members has been studied in detail. The La Barca-La Matosa strata display a global shallowing-upward depositional system capped by the lower Tremadocian erosive unconformity located at the La Matosa/Ligüeria contact. The La Barca strata overlie an essentially offshore-dominated sedimentary succession (lower part of the Oville Formation), and represent transitional marine-to-continental deposits with common alluvial sheet-flood sediments episodically reworked by wave activity. The La Matosa Member shows a global increase in grain size and bed thickness, from: (i) very fine-to-medium grained sandstones with shale interbeds arranged into coarsening-upward, unimodal sets and rich in parallel, lowangle, and cross laminae reflecting input of alluvial sand bars (Aramburu, 1989), although they were also interpreted as foreshore and sand ridges of a delta complex (Baldwin, 1977; Legg, 1985); to (ii) unsorted, coarse-grained sandstones displaying channels that represent migration of sheet (fluvial) braid-plain deposits. After the incision of a regional erosive unconformity, sedimentation led to deposition of a channelled braided fluvial system (the Ligüeria Member; Aramburu and García-Ramos, 1993). The latter occurs in disconnected outcrops reflecting sedimentation in isolated depocentres related to a synsedimentary tectonic activity, overlain by onlapping geometries.

As in other basins and platforms described in this paper, the Cantabrian platform was also episodically affected by tectonic instability. Aramburu and GarcíaRamos (1993) described the central (or central Asturias$\mathrm{N}$ León) palaeohigh and the San Emiliano-Beleño alignment, which may represent a major synsedimentary fracture. The central palaeohigh, situated in domains II and III, began its activity during the early Middle Cambrian and was re-activated across the CambrianOrdovician transition. Its geometry is suggested by sharp changes in thickness of the Oville and Barrios formations. The abundance of volcanoclastic beds at the top of the Matosa Member in domain III may suggest the instability of the platform related to volcanic activity. Transversally to the palaeohigh, the San EmilianoBeleño alignment is characterized by a distinct decrease in thickness from $\mathrm{N}$ to $\mathrm{S}$, and the disappearance of the Ligüeria Member to the South (domain V).

The Upper Cambrian of the West Asturian-Leonese Zone is also incompletely constrained. There, the socalled Cabos Series has been subdivided into three members: the lower member bearing Middle Cambrian trilobites and the upper one Early Ordovician ichnofossils (such as Cruziana furcifera, C. rugosa and C. cf. goldfussi; Baldwin, 1977). The middle member has yielded the polytoechioid brachiopod $P$. primigenius (Fig. 5) whose genus is restricted to the Tremadocian in Bohemia (Villas et al., 1995), Morocco, the Uralian margin of Baltica and Iran (Popov et al., 2001; Fortey and Cocks, 2003), and is associated in the Iberian Chains with earliest Tremadocian trilobites and pelmatozoan holdfasts (see above). The species occurs in storm-induced, brachiopod-dominated coquinas, 1$30 \mathrm{~cm}$ thick, and $c a$. $400 \mathrm{~m}$ below the supposed Cambrian-Ordovician boundary based on ichnofossils.

\subsection{Sardinia (Italy)}

Late Cambrian trilobites have been documented in the upper part of the Cabitza Formation in the Cabitza area and North of Domusnovas (Loi et al., 1995, 1996). They occur in fine-grained sandstones and siltstones probably representing a tide-dominated deltaic environment. Illustrated trilobites belong to the so-called faunal assemblage CAB 5b (Loi et al., 1995, 1996), which contains Macropyge sp., Maladioidella cf. colcheni, Micragnostus cf. haudei, Niobella cf. primaeva, Onchonotellus? amsassensis, Proceratopyge sp., a leiostegiid aff. Pagodia, a eulomid, and a calymenid. At Monte Cani this assemblage is succeeded by green siltstones containing (CAB 6) R. flabelliformis (Pillola and Gutiérrez-Marco, 1988; Pillola and Leone, 1993), P. geinitzi (Pillola, 1991), Oryctoconus cf. lobatus and related acritarchs. The younger assemblage is clearly of earliest Tremadocian age (Barca et al., 1987).

Late Cambrian conodonts (24 form-species of para-, proto- and euconodonts), correlatable with the lower 


\section{'TUBI' SECTION AT RAILWAY LINE CLOSE TO CABITZA STRATOTYPE, SW SARDINIA}

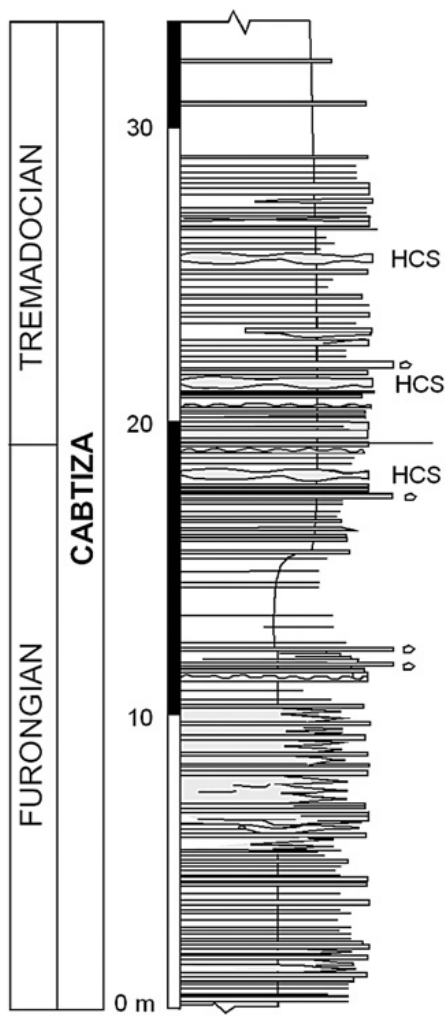

\section{LA CARIDAD SECTION, NAVIA AND HIGH SIL DOMAIN, WEST-ASTURIAN LEONESE ZONE, SPAIN}

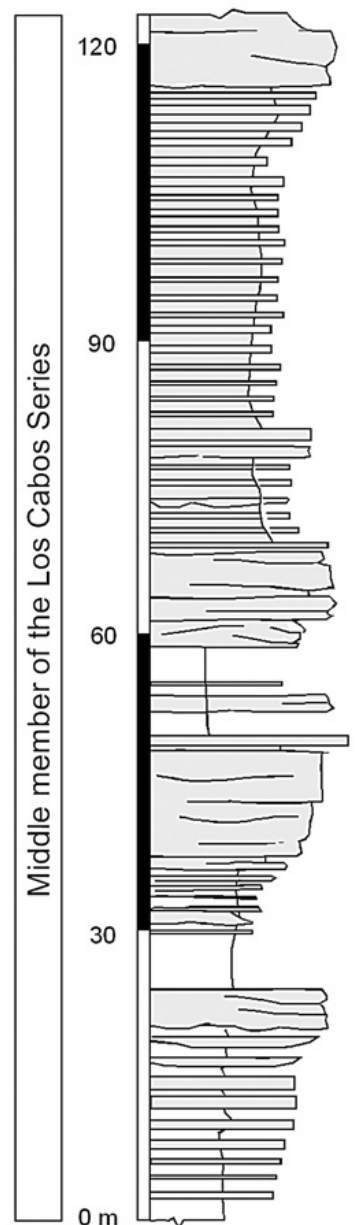

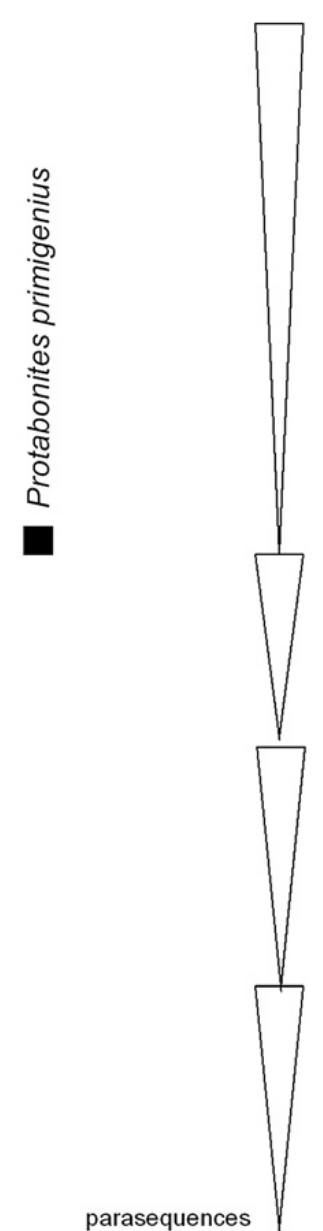

Fig. 5. Facies, fossiliferous levels and sequence-stratigraphic framework of the Cambrian-Ordovician transition from the La Caridad section of the West Asturian-Leonese Zone (modified from Villas, 1995), and the Cabitza 'Tubi' section from SW Sardinia (modified from Loi et al., 1995), see legend in Fig. 6.

Peltura Zone, have also been reported and figured from centimetre-thick calcareous lenses of the Cabitza Formation near Villamassargia, SW Sardinia (Serpagli et al., 1998).

A younger biostratigraphically significant level has been recently discovered in the Fluminese subregion (Monte Argentu-Piscina Morta area). This is characterized by a new graptolitic assemblage that includes the anisograptid Araneograptus murrayi (Hall, 1865), the dichograptids Clonograptus (Clonograptus) cf. rigidus (Hall, 1858), Clonograptus (Clonograptus) cf. multiplex (Nicholson, 1868), and two unassigned species of Didymograptus (Pillola et al., in press). The horizon of the upper part of the Cabitza Formation that has yielded A. murrayi documents a late Tremadocian-early Floian age. As a result, marine sedimentation persisted in SW Sardinia at least until the end of the Tremadocian.
The Cabitza Formation (Middle Cambrian to early Floian) consists of at least $600 \mathrm{~m}$ of siliciclastic strata displaying a monotonous succession in the Iglesiente and Sulcis areas (SW Sardinia). The formation is dominated by shales, bearing subordinate carbonate coquinas, and fine- to coarse-grained sandstones that increase in thickness upward. Loi et al. (1995) documented across the Cambrian-Ordovician transition a broad transgressive trend, although it is punctuated by a shallowing related to the occurrence of fossil assemblage CAB 6, and named by the authors 'the Acerocare Regressive Event' (sensu Erdtmann, 1986). The transition consists of shallowing-upward parasequences, 2-14 m thick, grading upsection from: (i) lower-offshore siltstones and claystones with local ripple cross-lamination; (ii) upper-offshore laminated shales and fine-grained sandstones; (iii) hummocky 
cross-bedded sandstones; and (iv) graded rhythmites interpreted as tidally influenced after an analysis of tidal bundles thickness (Fig. 5). The lower Floian part of the Cabitza Formation is unconformably overlain by the so-called Sardic Phase (Stille, 1939), where the involved stratigraphic gap affected a part of the Lower and Middle Ordovician, as the overlying Monte Argentu Formation is 'Caradoc' in age (Fig. 3).

Late Cambrian acritarchs have been recently described from the Arburese area (Ribecai et al., 2005), where the Mt. Fonnesu Sandstone has yielded acritarchs correlatable with the Peltura trilobite Zone of Newfoundland (sensu Parsons and Anderson, 2000). Other Late Cambrian acritarchs from low-grade metasediments of central Sardinia (the Solanas Sandstone) occupy a biostratigraphic range from the Agnostus pisiformis (?) to the Parabolina spinulus trilobite zones (Albani et al., 1985; Di Milia, 1991; Di Milia et al., 1993).

\subsection{The southern Montagne Noire (southern France)}

Late Cambrian trilobites, brachiopods and echinoderms occur in the Val d'Homs and La Gardie formations of the southern Montagne Noire. Both units are differentiable by the presence/absence of limestone intercalations, respectively. The La Gardie Formation is a siliciclastic succession, 5 to $500 \mathrm{~m}$ thick, and middle Languedocian (Middle Cambrian) to Tremadocian in age (Álvaro et al., 2001). It is composed of green shales with thin sandy intercalations at the top, and has been subdivided into three members: (i) the lower member, $60-100 \mathrm{~m}$ thick and middle Languedocian in age, consists of sandstone/shale rhythmites that pass basinward into homogeneous shales, and contains trilobites and cinctan echinoderms; (ii) the late Languedocian middle member (also named Sallèles Member; Fig. 6), up to $15 \mathrm{~m}$ thick, is composed of sandstones with subsidiary shales, can exhibit centimetre-thick limestone nodules at the top, and contains endemic trilobites, undetermined brachiopods and hyoliths; and (iii) the upper member, 0.5 to $5 \mathrm{~m}$ thick and Late Cambrian to Tremadocian in age, which consists of a shale-dominated succession, with green and purple colours, locally interbedded by sandstone beds. The fossiliferous Val d'Homs Formation, up to $300 \mathrm{~m}$ thick and also late Middle Cambrian to Tremadocian in age, consists of green and purple shales containing centimetre- to decimetre-thick, white, reddish and purple, lenticular to bedded limestones and yellow dolostones.

Late Cambrian trilobites were described for the first time by Feist and Courtessole (1984) from a limestone lens close to the base of the Val d'Homs Formation in Ferralsles-Montagnes (Pardailhan nappe). The authors recognized two species referred to Bergeronites latifalcatus and Prochuangia gallica. Subsequent collecting from the same lens has revealed the presence of further taxa: Abharella sp., Ammagnostus (A.) aff. sinensis, Kormagnostus? sp., Olentella cf. africana, Palaeadotes latefalcata, Paraacidaspis ultima, Proceratopyge (P.) spp., P. gallica, Shengia cf. spinosa, and Stigmatoa courtessolei (Shergold et al., 2000). The age of this fauna is judged to be similar to, but slightly older than that characterized by Maladioidella in the Demanda Sierra. The same limestone lens has yielded some linguliformean brachiopods that apparently do not cross the Middle-Upper Cambrian boundary elsewhere, such as Neotreta and Stilpnotreta (GonzálezGómez, 2005a), as well as Canthylotreta (L. Popov, pers. comm., 2007); as a result, its age was considered by the former author as related to the Middle-Late Cambrian transition interval. Elsewhere in the Montagne Noire, an assemblage containing trilobite species of Maladioidella, Onchonotellus, Probilacunaspis, Proceratopyge, Prochuangia, and a pseudagnostinid occurs in limestones of the Val d'Homs Formation (Álvaro et al., 2001, 2003a). This assemblage is the youngest Cambrian fauna found so far in the Montagne Noire, and has not yet been described nor illustrated.

The limestone strata and nodules of the Val d'Homs Formation display a widespread diversity of phosphatewalled brachiopods (Fig. 7A-L), which include acrotretids (Angulotreta brevis, Canthylotreta? n. sp., Dactylotreta n. sp., Dicondylotreta n. sp., Ferralstreta globosa, Neotreta sp., and Stilpnotreta magna), obolids (Lingullela sp.), scaphelasmatids (Eoscaphelasma n. sp.), siphonotretids (Schizambon convexus), and zhanatellids (Wahwahlingula? sp., Zhanatella rotunda) (González-Gómez, 2005a,b). Late Cambrian echinoderms are also abundant in the Val d'Homs Formation: they are represented by the mitrate Lobocarpus vizcainoi, several glyptocystitid cystoids such as Barroubiocystis radiata, Velieuxicystis ornata, and Scoteinocystis cambriensis, and a stromatocystoid (Stromatocystites sp.) (Ubaghs, 1998).

The earliest Ordovician has been traditionally marked by the appearance of $P$. geinitzi described by Sdzuy (1958) from reddish limestones and shales (Val d'Homs and La Gardie formations) just below the base of the overlying La Dentelle Formation. The occurrence of this species marks the base of its homonymous interval zone, traditionally reported as the oldest Tremadocian trilobite zone in the Montagne Noire (Vizcaïno and Álvaro, 2003). However, the recent finding of abundant conodont assemblages, belonging 


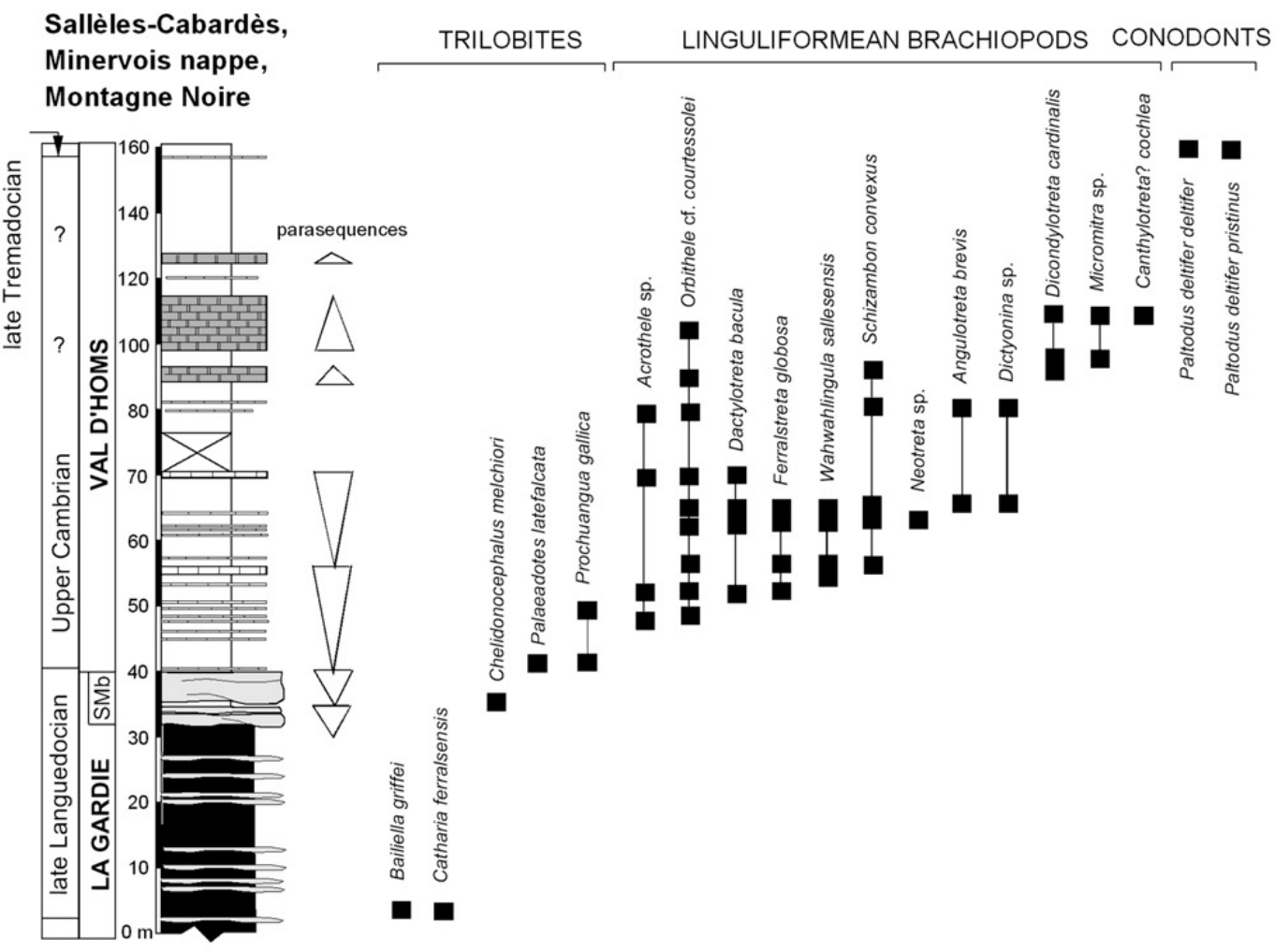

$\mathrm{SMb}$ : Sallèles Member

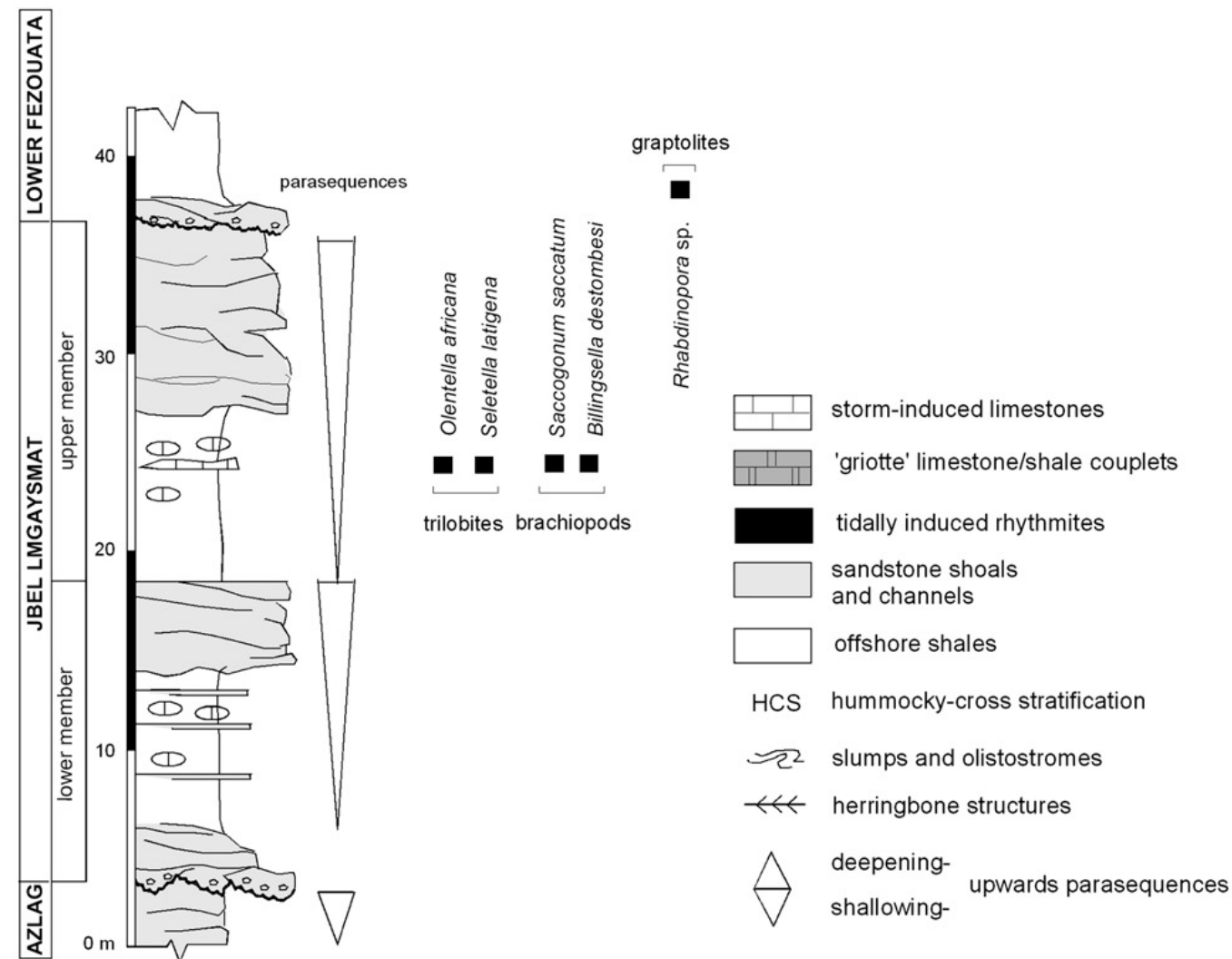

Fig. 6. Facies, fossiliferous levels and sequence-stratigraphic framework of the Cambrian-Ordovician transition from the southern Montagne Noire (Sallèles-Cabardès, Minervois nappe; modified from Álvaro et al., 2003b, 2005; González-Gómez, 2005b), and the Bou-R'bia section of the El Graara Massif (modified from Destombes, 1989). 
to the middle part of the Val d'Homs Formation in Sallèles-Cabardès (Minervois nappe; Álvaro et al., 2005) and to a limestone lens embedded in shales of the lowermost part of the Saint-Chinian Formation (Serpagli et al., 2007), allows a better constraint of the Upper Cambrian-Tremadocian boundary interval in the

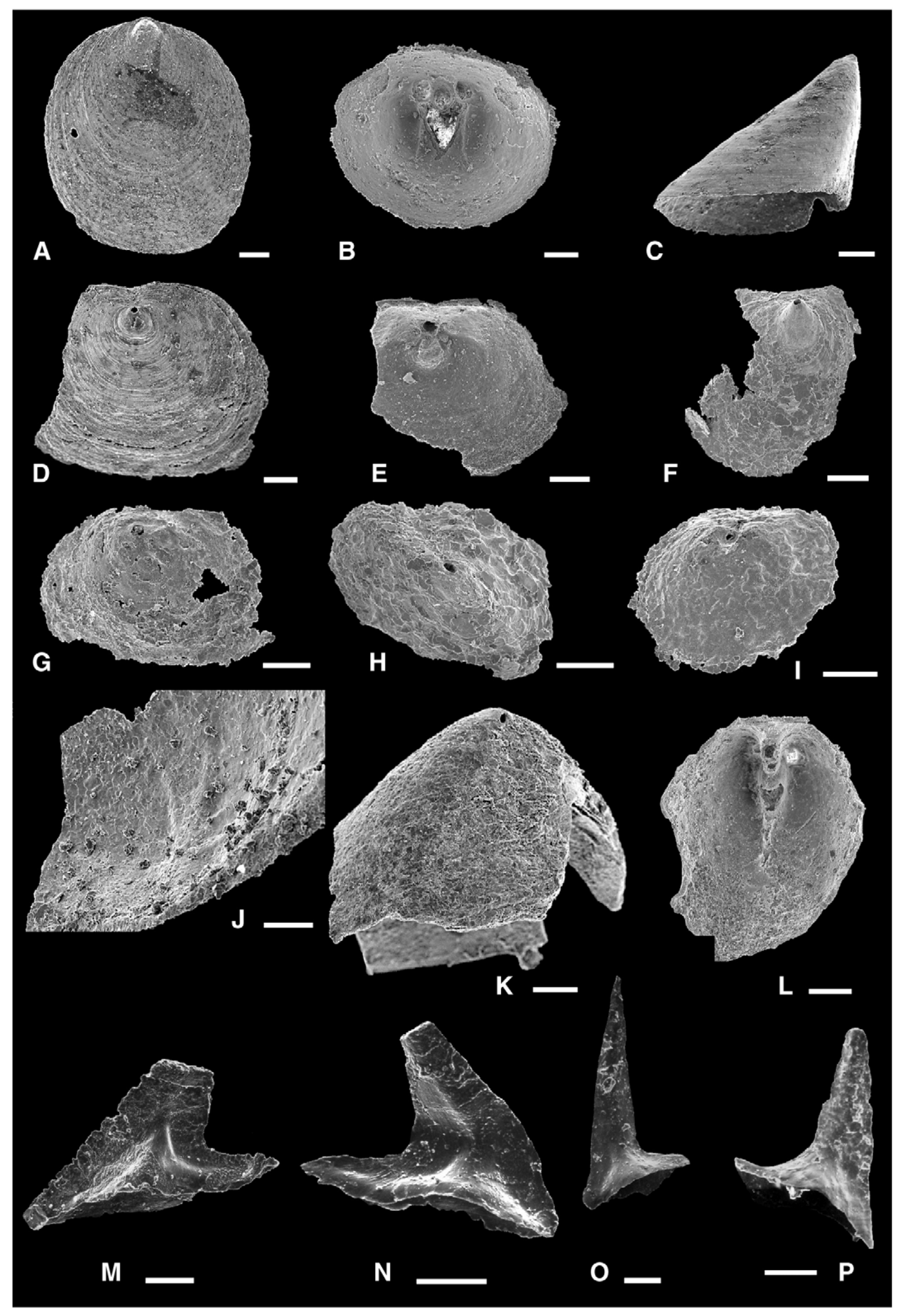


southern Montagne Noire. The fossiliferous level of Sallèles-Cabardès (Figs. 6 and 7M-P) has yielded in fact the conodont subspecies Paltodus deltifer pristinus (Viira, 1970) and Paltodus deltifer deltifer (Lindström, 1955), which allow attribution of the horizon to the $P$. deltifer Zone and, in particular, to the upper part of the zone (P. deltifer deltifer Subzone) on the basis of the following considerations. According to Szaniawski (1980), P. deltifer pristinus characterizes the older subzone of the $P$. deltifer Zone whereas $P$. d. deltifer is the index fossil of the younger subzone. In some areas of South-Central Sweden, $P$. $d$. pristinus co-occurs with P. $d$. deltifer but this appears to be in most cases the result of redeposition (Löfgren, 1997). In the same localities, $P$. d. deltifer spans also into the lowermost part of the overlying Paroistodus proteus Zone. Similarly, in our material, both $P . d$. pristinus and $P . d$. deltifer co-occur. Nevertheless, the former subspecies is represented by extremely delicate forms characterized by the same good preservation than $P$. d. deltifer elements. Based on this argument, we see no reasons to invoke redeposition to justify the concurrent presence of both subspecies in our material. Paltodus $d$. pristinus may therefore co-occur with $P$. d. deltifer at least in the lowest part of the P. d. deltifer Subzone. However, as we do not exactly know if this co-occurrence might extend higher up in the P.d. deltifer Subzone, it appears more reasonable for the moment to attribute the studied level to the whole $P$. $d$. deltifer Subzone.

It is well known that no agreement exists in the subdivision of the Tremadocian into two or three parts. In Great Britain, location of the historical type area, the Tremadocian is subdivided into two parts, named Cressagian and Migneintian (Fortey et al., 1995). Graptolite workers usually subdivide the Tremadocian into two parts, placing the boundary, according to the areas, at the first appearance of Psigraptus or Adelograptus tenellus (Zhang et al., 2004: Fig. 9). A threefold subdivision was also proposed by Erdtmann (1988). In the Montagne Noire, trilobite workers have been traditionally adopting a three-fold subdivision with P. geinitzi, Shumardia (C.) pusilla and Euloma filacovi zones characterizing the lower, middle and upper part of the Tremadocian, respectively (Vizcaïno and Álvaro, 2003; Tortello et al., 2006). However, this subdivision based on regional trilobites is at present under revision based on the recent discovery of conodonts. Conodont workers are currently using both a two- and three-fold subdivision of the Tremadocian. Some authors place the two-fold boundary in the uppermost part of the Cordylodus angulatus Zone (e.g., Zeballo et al., 2005: Fig. 3; Ortega and Albanesi, 2005: Fig. 2). In this case, the whole $P$. deltifer Zone would completely correspond to the Late Tremadocian. However, other conodont stratigraphers (such as Löfgren, 1997: pp. 264-265) subdivide the Tremadocian into three parts, with the $P$. d. pristinus Subzone marking the middle Tremadocian and the $P$. d. deltifer Subzone the late Tremadocian. Even in this case, the middle part of the Val d'Homs Formation in the Minervois nappe, corresponding to the P. d. deltifer Subzone, would be late Tremadocian in age.

In the southern Montagne Noire, studies focused on early Palaeozoic acritarchs are exclusively reduced to Martin's (1972) contribution from the Lower Ordovician Saint-Chinian Formation. We have tested the presence of acritarchs in Upper Cambrian, Langyashania-bearing shale beds from the uppermost part of the La Gardie Formation in the Campelou section (Pardailhan nappe). Unfortunately, preservation of organic-walled microfossils is not optimal and, associated with undiagnostic Leiosphaeridia Eisenack, 1958, and additional unrecognizable acanthomorphs and diacromorphs, only two distinct species were identified: Timofeevia phosphoritica Vanguestaine, 1978, and Cristallinium cambriense (Slavíková) Vanguestaine, 1978 (Fig. 8A-D). Timofeevia phosphoritica is a species found in the Mediterranean region (e.g., Algeria, Sardinia, and Turkey), Central and northern Europe, the Eastern European Platform, and eastern Newfoundland (Albani et al., 1991). Its known stratigraphic occurrence ranges from the Paradoxides paradoxissimus trilobite Superzone (Middle Cambrian; Martin and Dean, 1981) to the Peltura trilobite Zone (Late Cambrian; Martin and Dean, 1981). Cristallinium cambriense also shows

\footnotetext{
Fig. 7. Representative Late Cambrian brachiopods and Tremadocian conodonts from the Val d'Homs Formation of the southern Montagne Noire, reported from the first time in this work. A-C. Dactylotreta bacula González-Gómez, 2005: inner view of ventral valve; external view of dorsal valve; and oblique view of ventral valve; Ferrals-les-Montagnes. D-E. Ferralstreta globosa González-Gómez, 2005: external view of ventral valve; interior view of ventral valve; Ferrals-les-Montagnes. F-G. Canthylotreta? n. sp.; external view of ventral valve; interior view of ventral valve; Refescals ravine. H. Zhanatella rotunda Koneva, 1986; detail of the interior side of the dorsal valve; Refescals ravine. I-J. Eoscaphelasma n. sp.; external view of ventral valve; interior view of ventral valve; Refescals ravine. K-L. Dicondylotreta $\mathrm{n}$. sp.; external view of ventral valve; interior view of ventral valve; Sallèles-Cabardès section. M-N. Paltodus d. deltifer (Lindström, 1955), M elements; Sallèles-Cabardès section. O-P. Paltodus d. pristinus (Viira, 1970), M elements; Sallèles-Cabardès section. Brachiopod scales $=200 \mu \mathrm{m}$ and conodont scales $=100 \mu \mathrm{m}$. Brachiopod illustrated specimens are housed at the Muséum National d'Histoire Naturelle (Paléontologie), Paris, and conodont illustrated specimens at the Dipartimento del Museo di Paleobiologia e dell'Orto Botanico, Università di Modena e Reggio Emilia, Modena, under repository numbers IPUM 27992-27995, respectively.
} 


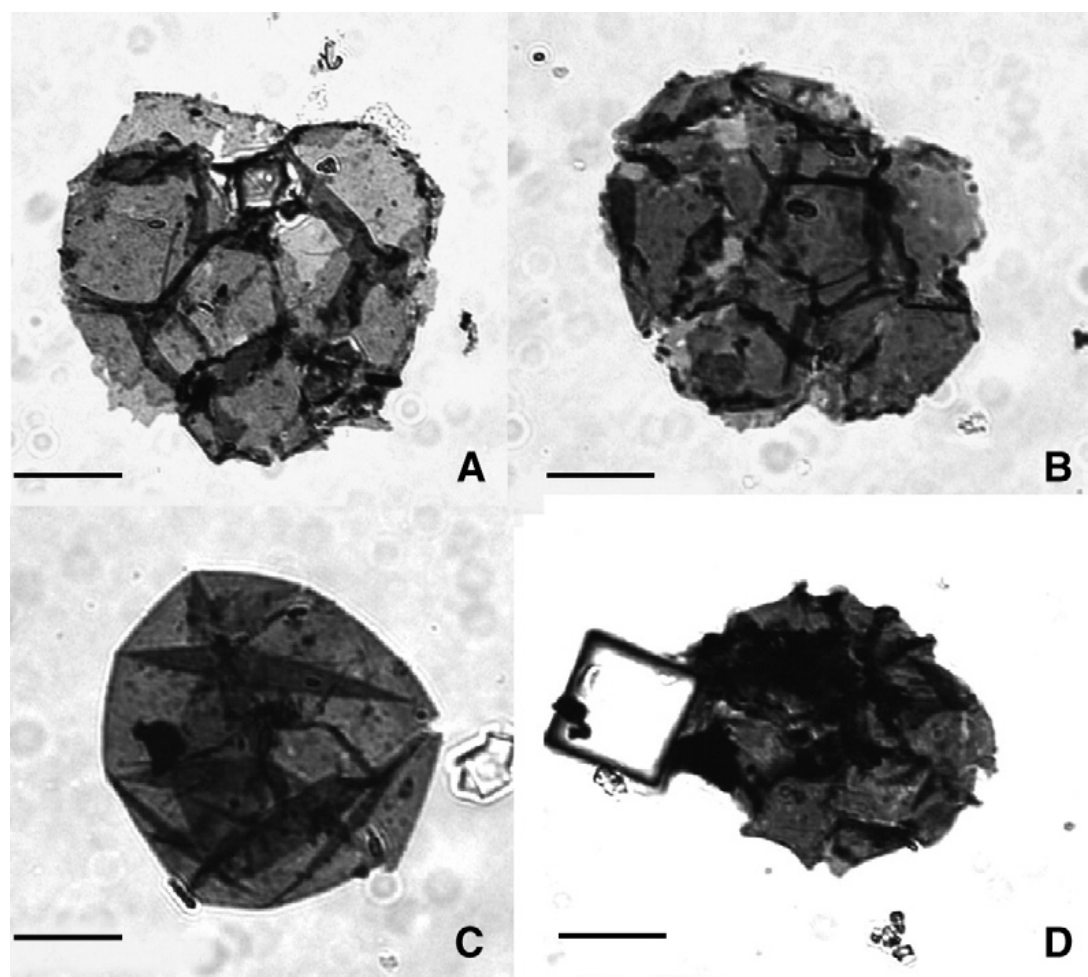

Fig. 8. Representative acritarchs from the Late Cambrian of the southern Montagne Noire (Campelou section; Pardailhan nappe), reported for the first time in this work. A-B. Cristallinium cambriense (Slavíková) Vanguestaine, 1978. C. Leiosphaeridia sp. D. Timofeevia phosphoritica Vanguestaine, 1978.

a worldwide palaeobiogeographic distribution, and its stratigraphic distribution ranges between the Ptychagnatus atavus-Tomagnostus fissus trilobite Zone (Middle Cambrian) in eastern Newfoundland (Martin and Dean, 1981) to the Cambrian-Ordovician transition (Cordylodus lindstromi conodont Zone in Dayangcha, Jilin Province, China; Yin Lei-ming in Chen et al., 1988). Therefore, diagnostic acritarchs from the Upper Cambrian are, by the moment, absent in the southern Montagne Noire.

In the proximal part of the southern-Montagne-Noire platform (Minervois nappe), the lower member of the La Gardie Formation consists of rhythmic, millimetre-thick, lenticular-bedded shale to wavy and flaser-bedded sandstone intervals associated with channels displaying complex lateral accretion patterns (Fig. 6). The preservation of millimetre-thick, claystone/sandstone rhythmites cut by meandering channels developed in tidal environments in the inner reaches of macrotidal estuaries affected by meander channels with reversely oriented foresets (Álvaro et al., 2003b).

Both the Sallèles Member and the La Dentelle Formation have erosive and abrupt lower and interbedded contacts, scouring into the underlying sediments. They comprise large-scale, trough and planar cross-beddings with sets ranging in thickness from 0.4 to $1.8 \mathrm{~m}$, topped by symmetric ripples and ripple lamination. They were deposited as short-crested megaripples and sandwaves. The association of sedimentary structures suggests a shallow platform dominated by wave activity, and minor storm reactivation related to interbedded erosive contacts. Episodes in which the bedforms ceased to migrate allowed colonization by an open-sea benthic community. Strata are generally incorporated into coarsening-upward parasequences (0.8-1.2 m thick): from bottom to top, almost all the parasequences display a systematic succession in which the finer-grained storm deposits are gradationally or sharply covered by the coarser-grained sandstones. At the top of some parasequences occur erosive and truncating surfaces, partly stained by iron oxides, and locally highly bioturbated by Skolithos and Arenicolites. Shoaling (prograding trends related to shallowing-upward fluctuations of the relative sea level) during times of rapid sediment influx offers a simple and repeatable mechanism for creating these coarseningupward parasequences, topped by bioturbated hardgrounds (Álvaro et al., 2003b).

The stratigraphic interval bounded between the Sallèles Member and the La Dentelle Formation is represented by the offshore shale-dominated upper member of the La Gardie Formation and the heterolithic strata of the Val d'Homs Formation. In the latter, two 
kinds of limestone/shale alternations occur: the socalled 'griotte' and carbonate tempestites. The 'griotte' consists of centimetre-thick alternations of bedded to nodular limestone and shale exhibiting reddish to purple colours. The thicker carbonate beds (up to $20 \mathrm{~cm}$ thick) are dominated by packstone textures, including disarticulated to broken trilobites, echinoderm ossicles, hyolith-like shells, chancelloriid sclerites, carbonateand phosphate-shelled brachiopods, and rarer conodonts and sponge spicules. The thinner limestone beds and nodules (less than $5 \mathrm{~cm}$ thick) are mainly wackestones rich in the same fossil assemblage, in some cases displaying erosive local contacts and grading, up to $1 \mathrm{~cm}$ thick. Cycles or alternations exhibit a repeated increasing-upward shale/limestone ratio, starting with limestone beds with stylonodular textures and millimetrethick clay seams, grading upward into shales with isolated thin limestones. The rhythmic alternation in lithology indicates periodic fluctuations in carbonate productivity and/or supply of fine siliciclastic sediments, the latter inhibiting the former. The thicker limestone intercalations have recorded the influence of bottom currents and waves (shoreface), while the thinner ones illustrate quieter conditions interrupted by high-energy pulses (offshore). The repeated (decimetreto metre-thick) changes reflect deepening-upward trends where bioclastic pavements correspond to distal expressions of storm-induced processes. The most distinct feature of this facies association is its important lateral variation of thickness. Similar variegated limestone/ shale alternations are known from the Lower-Middle Cambrian transition of southwestern Europe (named 'griotte' by their colour), and currently represent carbonate deposition on tectonically induced palaeohighs, whereas shale deposition took place in relative, laterally equivalent depressions.

The alternating shale and bioclastic (tempestitic) limestones, 0.1 to $1.4 \mathrm{~m}$ thick, display sharp and erosive contacts. Bioclastic limestones consist of packstones to wackestones, whose main constituents are poorly-sorted trilobites, echinoderms, sponge spicules, chancelloriid sclerites, calcite- and phosphate-shelled brachiopods, and conodonts. The preservation of a non-fragmentary fossil record and high mud content alternating with fragmented skeletons and graded units, with erosive lower contacts, indicates that the substrate was episodically affected by storm events.

Slope-related deposits are abundant in the Upper Cambrian La Gardie and Val d'Homs formations of the southern Montagne Noire. These consist of shales and sandstone alternations episodically characterized by a chaotic arrangement of contorted beds, interrupted by truncation surfaces, intraformational slumps and synsedimentary bedding distortion. These structures are interpreted as having undergone different types of down-slope movements by basal sliding of plastic to semi-rigid sediment masses. The reworked material was developed on slopes close to the sedimentary environments from which they were derived. The lack of breccia deposits and rhythmic turbidites suggests lowangle slopes, in contrast with the conventional steeped submarine fan models, which imply base-of-slope to basin deposition dominated by turbidites.

The La Dentelle sedimentation occurred when shoreline and nearshore facies prograded across a tectonically induced palaeotopography, as a result of an increase in terrigenous supply and establishment of regressive conditions. During deposition of the La Dentelle Formation, the inherited palaeorelief disappeared or was highly attenuated, since the coarse-grained siliciclastics extended to the whole platform, and no tectonic interruptions are recorded. At the end of the $\mathrm{La}$ Dentelle progradation, a subsequent abrupt relative sealevel rise caused a marked change in depositional patterns, marked by a correlatable glaucarenite. This documents a major transgressive surface reflecting a sharp change in the style of sedimentation and the flooding of the platform. Continued transgression during Tremadocian times (Saint-Chinian Formation) flooded most of the platform, where tectonically induced 'griotte' facies are still residual in some areas (Mounio Formation; Álvaro et al., 2003b).

From a sequence-stratigraphic point of view, the La Gardie-Val d'Homs-La Dentelle sedimentary succession represents a composite retrogradational-progradational (or transgressive-regressive) depositional system. The lower retrogradational (transgressive) depositional system is characterized by a vertical succession from mixed tidal (estuarine?) flats and channels (back-shoal heterolithic beds of the lower member of the La Gardie Formation), covered by shoreface to foreshore shoal complexes (Sallèles Member), and capped by the upper member of the La Gardie Member and the Val d'Homs offshore sediments. The Val d'Homs, outer-platform sedimentation was dominated by suspension setting of mud under fair-weather conditions punctuated by sharp storm events. The difference in sedimentation rates of both carbonate and siliciclastic substrates suggests establishment of topographic highs on the platform where isolated windows of carbonate productivity were rhythmically intense in the 'griotte' facies, surrounded by deposition of terrigenous sediments on adjacent lows or depressions. This was laterally accompanied by relatively common high-energy currents transporting 
sediment down-slope as a result of high-slope instabilities resulting in slumping, sliding and debris flow. In contrast, coeval deposition on intra-platform ramp settings was marked by much quieter conditions where substrate stability was higher.

Although the Cambrian-Ordovician transition of the southern Montagne Noire did not record volcanic events but a rather extensive regime inducing palaeotopographies, a major extensional regime was recorded across the transition in other areas of the French Massif Central involving an episodic input of tholeiitic intra-plate lavas and tuffites (Guérangé-Lozes and Burg, 1990; Ledru et al., 1994).

\subsection{The Anti-Atlas (Morocco) and neighbouring areas}

The Upper Cambrian of Morocco has been exclusively reported in the Jbel Lmgaysmat Formation (Tabanite Group; Destombes et al., 1985). Its outcrops seem to be limited to a part of the El Graara Massif (Central Anti-Atlas), a geographic extension that is probably related to the erosive unconformity that overlies the unit. The formation consists of shales and fine-grained sandstones, with thin calcareous layers and nodules rich in fossil fragments (Fig. 6). The base of the Jbel Lmgaysmat Formation, up to $35 \mathrm{~m}$ thick, is an erosive discontinuity covered by a conglomeratic to coarse-grained sandstone that displays cross-bedded sets, is strongly limonitized, and rich in rhyolitic gravels (Destombes et al., 1985; Destombes, 1989). Two shallowing-upward parasequences are recognized, 10$15 \mathrm{~m}$ thick, dominated by shales with isolated, centimetre-thick limestones rich in trilobites and brachiopods, and topped by respective iron-stained sandstone shoals. The upper parasequence is capped by up to $10 \mathrm{~m}$ of amalgamated, trough cross-bedded sandstone sets. They are overlain by an erosive unconformity that, laterally, cuts into the underlying strata leading to a sharp decrease in thickness (from SW to NE) and final disappearance of the Jbel Lmgaysmat Formation. The overlying Lower Fezouata Formation begins with a conglomeratic bed, less than $1 \mathrm{~m}$ thick, which passes laterally into a glauconite-rich, coarse-grained sandstone, on the top of which occurs the first debris of $R$. flabelliformis in a shale-dominated succession.

Scattered coquinas interbedded with shales of the Jbel Lmgaysmat Formation have yielded the trilobites Olentella africana and Seletella latigena (Destombes and Feist, 1987), and the brachiopods Saccogonum saccatum and Billingsella destombesi (Havlíček, 1971). The presence of additional aphelaspid and elviniid trilobite species associated with debris of Saccogonum has also been reported in the Central Anti-Atlas (Geyer et al., 2002), but this fauna has not yet been described nor illustrated.

The erosive unconformity that overlies the Jbel Lmgaysmat Formation has been correlated with the Sardic unconformity (Michard, 1976) or with epeirogenic uplifts (Destombes et al., 1985). The hiatus is common to all North-African basins from Morocco through Algeria, Libya, and Tunisia (Crossley and McDougall, 1998). Crossley and McDougall (1998) reported evidence for block faulting and marked angular unconformities in Algeria, although similar evidence is absent in the Anti-Atlas of Morocco, where some lateral thickness changes are subtle at best, and strongly overprinted by later folding (Burkhard et al., 2006).

\section{Toward an integrated sequence-stratigraphic framework}

Although a biostratigraphic subdivision of the Upper Cambrian is still unavailable in the western Mediterranean region, some tie points can be made based on trilobite, brachiopod and echinoderm faunas. This leads to the recognition of a succession of transgressiveregressive packages, commonly bounded by regionally correlatable, erosive unconformities. As regressive strata represent nearshore platform and continental facies, age-diagnostic fossils are not always common in the regressive packages.

\subsection{Relative sea-level fluctuations}

As illustrated in Fig. 3, Upper Cambrian sedimentation was relatively continuous and devoid of significant stratigraphic gaps in the southern Montagne Noire and the Iberian Chains. There, Upper Cambrian strata are bracketed by two major regressive trends. Both regressions are topped by: (i) an uppermost Middle Cambrian discontinuity related to the progradation of back-shoal environments, some of them tidally influenced (lower part of the La Gardie and Valdeorea-Torcas formations; Álvaro, 1995; Álvaro et al., 2003b); and (ii) an uppermost Cambrian-lower Tremadocian unconformity related to the progradation of foreshore to shoreface, shoal complexes (La Dentelle and Valconchán formations; Álvaro et al., 2003b). In this context, the Upper Cambrian sedimentation developed a broad transgressive-dominated depositional system, with common offshore deposits and both clayey and carbonate substrates (upper part of the La Gardie/Val d'Homs and Valtorres formations; Álvaro and Vennin, 1996a; Álvaro et al., 2003b). 
The base of the G. reticulatus Zone coincides in the Jiangnan Slope Belt (Hunan, China), the type area where the GSSP for the base of the Furongian has been defined, with the initial stages of a transgression (Yang and $\mathrm{Xu}$, 1997). Transgression coinciding with the lower part of the G. reticulatus Zone is followed by a highstand phase and then a regression documented in South and North China (Yang and Xu, 1997). This regression is represented in Laurentia by the Sauk IISauk III hiatus (Palmer, 1981; Osleger and Read, 1993; Saltzman et al., 2000). In addition, the 'Acerocare Regressive Event' of Erdtmann (1986) is the base of the Tremadocian traditionally applied in Scandinavia. Nicoll et al. (1992) redefined it to refer only to the regressive peak at the top of its homonymous zone, and correlated it with the base of the Warendian in shelf sediments of Australia. Subsequently, Artyushkov et al. (2000) reinterpreted the 'Acerocare Regressive Event' as a result of a misinterpretation influenced by a synsedimentary tectonic uplift, and not by eustatic fluctuations, recorded in Oeland and southern Sweden during the Tremadocian. Accordingly, this regressive event cannot be used as an argument for intercontinental correlation.

As a result, the Cambrian-Ordovician transition seems to be globally represented by a regression, probably of eustatic character, which was slightly diachronous in southwestern Europe. The regression represented by the progradation of the La Dentelle (Montagne Noire) and Valconchán (Iberian Chains) formations culminated with the record of distinct erosive unconformities (Fig. 9). This was also reflected in SW Sardinia by the record of tidally induced rhythmites in the condensed Cabitza Formation (Loi et al., 1995). The erosive unconformity that tops this regression is distinctly diachronous: it took place in the Iberian Chains at a virtual CambrianOrdovician boundary interval (the lower part of the Valconchán Formation contains Late Cambrian trilobites, whereas its upper part has yielded early Tremadocian echinoderms), and in the southern Montagne Noire within the $P$. geinitzi (Tremadocian) Zone. The delayed progradation of foreshore and shoreface depositional systems in the southern Montagne Noire was probably due to the record of subsidence perturbations. These are indicated by the abundance of slope-depositional facies in the La Gardie, Val d'Homs, Mounio and Saint-Chinian formations, and sharp lateral variations in thickness that favoured an episodic development of palaeotopographies, only buried by the progradation of the La Dentelle sandstone shoals (Álvaro et al., 2003b).

\subsection{Erosive unconformities and related gaps}

In the Anti-Atlas, the Cantabrian Zone, SW Sardinia, and the southern Montagne Noire a Late CambrianEarly Ordovician regression truncated large areas of their platforms. The related gaps are diachronous, becoming younger from SW to NE: (i) the gap can include the entire Upper Cambrian in the Anti-Atlas; (ii) it ranges from lower Upper Cambrian to the Tremadocian-Floian transition in the Cantabrian Zone; (iii) from lower Tremadocian to the '5th-Ordovician' stage in SW Sardinia; and (iv) from the Floian-'3rd Ordovician' stage transition to the '5th Ordovician' (Sandbian) stage in the southern Montagne Noire (Fig. 3). In addition, the Armorican Massif does not have a record of Upper Cambrian strata, due to the existence of a gap that ranges from uppermost Lowerlowermost Middle Cambrian to the transition across the Floian and '3rd Ordovician' stages (see a synthesis in Paris et al., 1999). By contrast, sedimentation in the Iberian Chains was relatively continuous across Late Cambrian and Tremadocian times (Fig. 3). There, some authors (e.g., Wolf, 1980; Babin and Hammann, 2001; Gutiérrez-Marco et al., 2004) placed a stratigraphic hiatus at the top of the Armorican Quartzite; however, its sedimentological implications and biostratigraphic gap have not yet been described in detail.

The aforementioned gaps can be related to nondeposition and erosion, but their diachronous migration across the Late Cambrian and Early-Middle Ordovician, in a palaeogeographic SW-NE transect, suggests a possible common geodynamic origin. Gaps were also preceded and succeeded by tectonic instability and intra-continental extension in the western Mediterranean region, favouring episodic development of palaeotopographies.

The Late Cambrian hiatus recorded in Morocco and adjacent areas has been interpreted as related to a phase of neighbouring rifting (further North) and concomitant erosion on southern rift shoulders (Burkhard et al., 2006). A possible explanation for the SW-NE diachronous shift of the aforementioned erosive unconformity may be related to an associated northeastward migration of a northern rift that led to numerous magmatic and plutonic episodes of tholeiitic and alkaline affinities. In the Cantabrian Zone, Heinz et al. (1985) and Loeschke and Zeider (1982) described: (i) sills intruded into not yet lithified shales and sandstones of the Oville Formation; and (ii) pyroclastic rocks forming the infill of several hydrothermal craters and pipes caused by phreatomagmatic eruptions; most of the necks are cut off by erosion shortly below the unconformity of the La Matosa/Ligüeria 


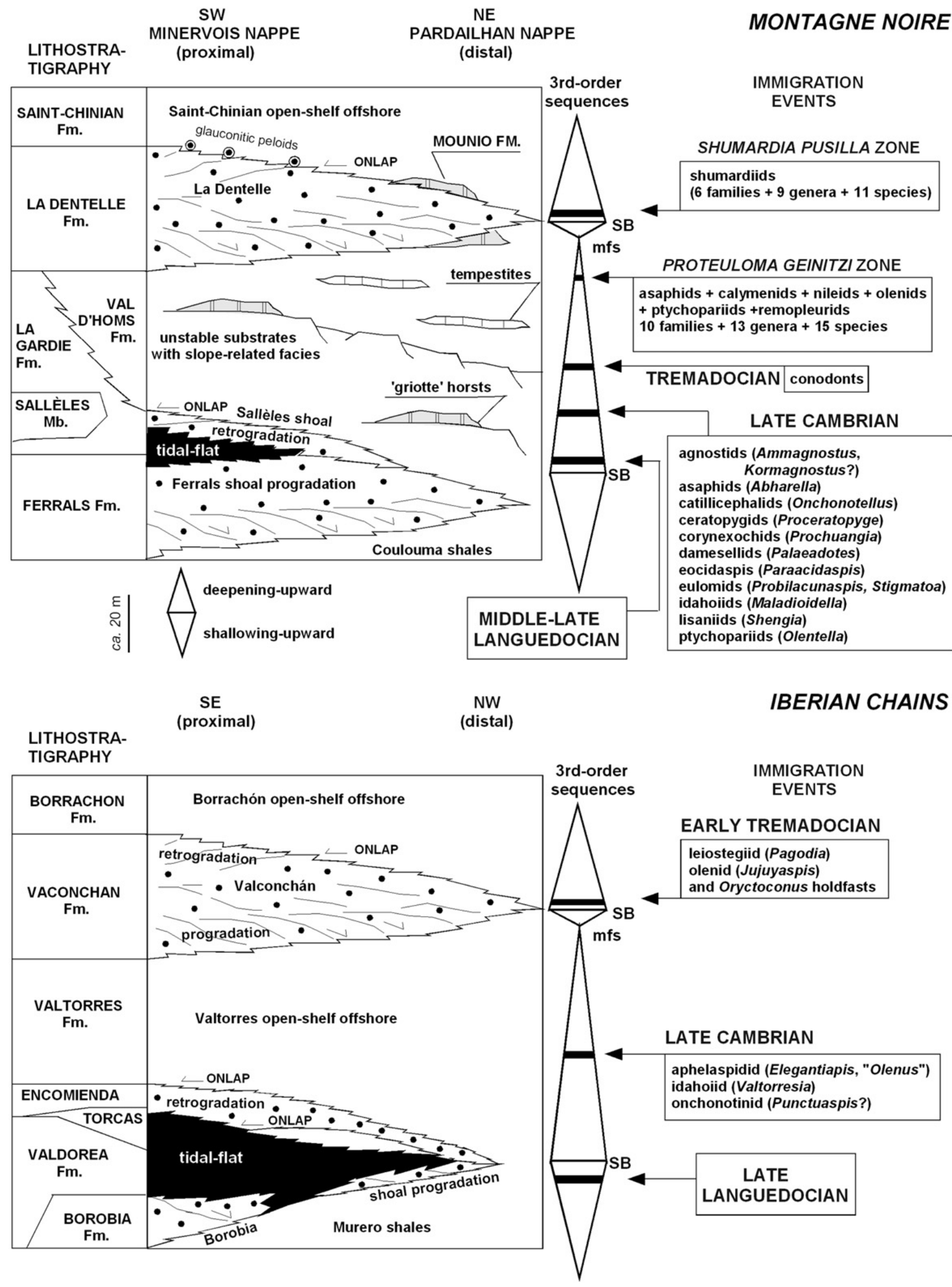

Fig. 9. Integrated stratigraphic comparison of the Late Cambrian from the southern Montagne Noire and the Iberian Chains, showing the relationship between immigration events, biostratigraphy and third-order sequences. 
contact. The authors described all these volcanic products as belonging to a same magmatic phase, where the volcanic bombs, subvolcanic xenoliths and pyroclastic rocks are geochemically assigned to alkaline olivine basalts and trachy-basalts. As a result, the late Middle Cambrian to Tremadocian volcanic activity recorded in the Cantabrian Zone was interpreted as connected with rifting and mantle-plume processes that also affected the continental crust of the northwestern Hesperian Massif (Van Carlsteren and Den Tex, 1978; Van der Meer Mohr et al., 1981). Lower Ordovician lavas and plutonic rocks of the Armorican Massif are also tholeiitic and alkaline, and characterize intra-plate extensions (Cabanis, 1986). The Lower Ordovician tholeiites of the Albigeois (northern Montagne Noire) suggest crustal thinning (Marini, 1988) and intra-plate magmatism (Guérangé-Lozes and Burg, 1990; Ledru et al., 1994). The base of the Ordovician Series in the Central and western Pyrenees has rhyolitic interbeds (sills and rare lava flows) and conglomeratic layers rich in rhyolitic debris (Majeste-Menjoulas and Debat, 1994), where Lower Ordovician granitoids and metavolcanic rocks are common (Calvet et al., 1988; Deloule et al., 2002). In the Ollo de Sapo domain of the Central Iberian Zone, widespread Lower Ordovician granitoid intrusions of Floian age are followed by the Toledanian unconformity (Valverde-Vaquero and Dunning, 2000). The eventual end of the Avalonian detachment seemingly caused the final deformational overprint at the Middle Ordovician Sardic Phase in Sardinia. Pre-Sardic strata folded generally under very low-grade metamorphic conditions but at its type locality in SW Sardinia the Sardic Phase is not considered as an orogenic event, but related to rifting and evolution of the Rheic Ocean (Helbing and Tiepolo, 2005).

Another volcanosedimentary complex related to the opening of the Rheic Ocean is recorded in the OssaMorena Zone (SW Iberian Peninsula). There, progressive crustal thinning, inducing rifting and the building of a volcanically active passive margin facing southward to the future Rheic Ocean, represents the first volcanic stages associated with the drift between NW Gondwana and Avalonia (Etxebarría et al., 2006). Rifting propagated diachronously across the zone from the Early Cambrian to the Late Ordovician, but by Early Ordovician time, the existence of a significant tract of new ocean is evidenced by a breakup unconformity (Sánchez-García et al., 2003). Finally, the Tremadocian-early Floian is also marked by a period of break-up of the Uralian margin of Baltica. This faced southward the NW Gondwanan margin at the beginning of the Ordovician (Torsvik and Rehnström, 2001), and recorded the birth of a new rifting zone located in SE Baltica (Sturesson et al., 2005).

\section{Ecostratigraphic patterns}

The scarcity of biostratigraphically significant fossils has not favoured the proposal of any fine chronostratigraphic subdivision in the Upper Cambrian of the western Mediterranean region. Correlation of their strata is approximated with spot horizons, and the actual base of chronostratigraphic links is only approximate and can suffer further modifications in the future depending on new fossil findings.

\subsection{Major benthic community replacements}

During the Cambrian, the western Gondwanan margin is commonly portrayed as oriented approximately SWNE in the southern hemisphere (McKerrow et al., 1992). As a consequence of this orientation, the shape of the tropical zones was affected by the course of major ocean currents transporting cool waters toward the tropics. This would have caused the tropics to occupy a narrower latitudinal area on this western margin respect to the eastern margins (Briggs, 1995). As stated by Álvaro et al. (2003a), this inferred palaeogeographic situation may be compared with that of the western Australian margin during the Eocene, when Australia and Antarctica were close enough to prevent the development of a circumAntarctica circulation (McGowran et al., 1997). As a result, two main surface circulation patterns took place: a South-Equatorial Current flowing (up to the Recent) as a low-salinity surface component of the global thermocline system, and a western Australian current (parallel to the western face of Australia) that disappeared with the Eocene opening of a gap between both continents. Apparently, a similar western Gondwanan SW-NE current rising in latitude from polar areas operated during Cambrian times, contrasting with an opposite (NE-SW) current bringing subtropical waters into this temperate Gondwanan margin. The variable dominance of both currents directly affected faunal migrations and palaeoclimates.

A shift from subtropical carbonate-dominated platforms to temperate-water siliciclastic platforms is attributed to changing oceanographic and palaeoclimatic conditions across the Middle-Late Cambrian transition, when the southward-moving subtropical margin of NW Gondwana progressively invaded temperate and cold seas. The episodic development of Late CambrianTremadocian carbonate factories within temperate-water settings of the southern Montagne Noire (Val d'Homs and Mounio formations) signals short-lived warming episodes in meridional parts of NW Gondwana. These carbonate substrates represent sporadic development of 
Languedocian-Late Cambrian chancelloriid-echinoderm-sponge $(C E S)$ relics, also rich in linguliformean brachiopods and trilobites, which were widely distributed during the Early and Middle Cambrian. This association changed during the Tremadocian, as indicated by the disappearance of chancelloriids and the input of conodonts.

By contrast, the same cooling trend, from subtropical to temperate waters, was marked differently in siliciclastic substrates. Álvaro and Vennin (2001) described in the Iberian Chains the successive decline and disappearance of: (i) late Early Cambrian ooids, evaporite relics and microbial carbonates; (ii) chancelloriid-echinodermsponge meadows crossing the Early-Middle Cambrian transition; (iii) Middle Cambrian hydrodynamic bioclastic carbonates related to the contraction of carbonate factories into increasingly narrow belts ('griotte' facies); (iv) a late Middle Cambrian increase of trilobite-dominated communities on clayey substrates; and (v) late Middle-Late Cambrian impoverished benthic communities dominated by linguliformean brachiopods in sandy shoals and trilobites on open-sea, clayey substrates. The Languedocian-Late Cambrian interval seems to mark in these substrates the culmination of a cooling trend as shown by the pervasive decrease in trilobite biodiversity (Álvaro et al., 2003a), associated with the drastic disappearance of bioclastic carbonates.

Late Cambrian trilobites are scattered in the western Mediterranean region compared with the abundance recorded in Lower and Middle Cambrian strata of the same area. This suggests that the Late Cambrian, temperate-water faunas of the margin were less diverse and more impoverished than the EarlyMiddle Cambrian subtropical ones. However, the palaeoclimatic modification related to the southward drift of NW Gondwana was not the single control on biodiversity. For instance, Late Cambrian faunas from the British Islands (eastern Avalonia) and Baltica are extremely rich and diverse. This wealth is directly controlled by the distribution of the prolific (although sampling biased) olenid biofacies, which was environmentally, not climatically controlled, and is absent in the western Mediterranean region.

\subsection{Immigration events and their control on biostratigraphy}

As indicated above, a common Languedocian regression has been recorded in the southern Montagne Noire and the Iberian Chains. In both platforms, the regression is characterized by progradation of a siliciclastic rimmed platform with three major deposi- tional systems, in ascending order (or from distal to proximal environments): (i) offshore clayey substrates (Coulouma and Murero formations); (ii) shoal complexes sequentially arranged in shoaling parasequences (Borobia and Ferrals formations); and (iii) tidally induced rhythmites (mixed tidal flats; Valdeorea and proximal outcrops of the lower member of the $\mathrm{La}$ Gardie formations) and back-shoal bioturbated siltstones (Torcas Formation). Late Languedocian trilobites are recognized in the Borobia and La Gardie/Val d'Homs formations, and are dominated: (i) in the Montagne Noire, by agnostids (Megagnostus and Pseudoperonopsis), paradoxidids (Eccaparadoxides), conocoryphids (Bailiaspis, Bailiella, Conocoryphe, and Holocephalina), solenopleurids (Jincella), agraulids (Skreiaspis), proasaphiscids (Chelidonocephalus, Derikaspis), dorypygids (Dorypyge), and the last record of cinctans (Sucocystis); and (ii) in the Iberian Chains, by an impoverished assemblage of conocoryphids and paradoxidids. The conocoryphid-paradoxidid-solenopleurid assemblage was one of the typical Leonian-Caesaraugustian-early Languedocian (Middle Cambrian) trilobite associations of the Acado-Baltic province sensu Sdzuy (1972). During the late Languedocian, this palaeobiogeographic pattern changed with the input of more cosmopolitan invaders (e.g., Chelidonocephalus, Derikaspis, and Dorypyge) that firstly co-occurred with species of the conocoryphid-paradoxidid-solenopleurid assemblage, and subsequently replaced them.

In the southern Montagne Noire, the succeeding late Languedocian-early Tremadocian transgression is characterized by a stepwise immigration of new trilobite families. Several events can be distinguished:

(i) A re-colonization of offshore substrates, coinciding with the retrogradation of the Sallèles shoal complex, was made by paradoxidids (Eccaparadoxides), dorypygids (Dorypyge) and, for the first time, anomocarids (Abharella). This event marks a distinct episode during which the shoal complexes of the Sallèles Member ceased their migration and allowed colonization of sandstone substrates by this faunal assemblage.

(ii) The retrogradation of coarse-grained siliciclastic packages allowed establishment of open-shelf (offshore) conditions and, in the Montagne Noire, of carbonate factories. In the Iberian Chains, the Late Cambrian immigration (Valtorres and lower part of Valconchán formations) is represented by aphelaspidids (Elegantiaspis, “Olenus"), idahoiids (Valtorresia), olenids 
(Jujuyaspis), and onchonotinids (?Punctaspis). This event is much more diversified in the shale/ limestone alternations of the southern Montagne Noire (Val d'Homs Formation), where it is characterized by the input of agnostids (Ammagnostus, ?Kormagnostus), anomocarids (Abharella), aphelaspidids (Olentella), catillicephalids (Onchonotellus), ceratopygids (Proceratopyge), damesellids (Palaeadotes), eulomids (Probilacunaspis, Stigmatoa), idahoiids (Maladioidella), lichakephalids (Paraacidaspis), lisariids (Shengia), pagodiids (Prochuangia), as well as new echinoderm faunas.

(iii) After the first record of isolated Tremadocian conodont-rich lenticular limestones at the middle and upper parts of the Val d'Homs Formation (Montagne Noire; Küppers and Pohler, 1992; Álvaro et al., 2005), an abrupt trilobite turnover is recorded in the reddish and purple shales and limestones that underlie the La Dentelle Formation. This immigration marks the base of the $P$. geinitzi Zone, and contains a rich trilobite assemblage composed of agnostids (?Anglagnostus, Geragnostus and Leiagnostus), asaphids (Niobella and Symphysurina), calymenids [Platycalymene (Pharostomina)], catillicephalids (Onchonotellus), possible hystricurids (Holubaspis), nileids (Hemibarrandia), and remopleurids ( $\mathrm{Ma}$ cropyge). The oldest Tremadocian trilobite record represents a sharp immigration of highly diverse trilobites, which comprise 10 families, 13 genera and 15 species. In Sardinia, $P$. geinitzi (reported in the C6 assemblage of Loi et al., 1995) is associated with the graptolite $R$. flabelliformis, earliest Ordovician acritarchs (Barca et al., 1987) and the pelmatozoan holdfast $O$. lobatus. The latter cooccurs in the Iberian Chains with leiostegiids (Pagodia), representing a re-colonization of nearshore substrates (Valconchán Formation).

After the delayed installation of a progradational, coarse-grained siliciclastic platform in the southern Montagne Noire (La Dentelle Formation), a new immigration phase is recorded both in carbonate and siliciclastic substrates (Mounio and Saint-Chinian formations, respectively). By comparison with the $P$. geinitzi Zone, a relatively impoverished trilobite assemblage is recognized with only 6 families, 9 genera and 11 species, in which the exceptional occurrence of the family Shumardiidae is remarkable. This immigration event allows the identification of the base of the Shumardia (C.) pusilla Zone, located in the lowermost part of the Mounio and Saint-Chinian formations. The drastic trilobite turnover recorded across the $P$. geinitziShumardia (C.) pusilla zone transition, related to the onset of regressive conditions, involved the disappearance of all the previously known species. The Shumardia (C.) pusilla Zone comprises a new trilobite assemblage mainly composed of agnostids (Anglagnostus and Geragnostus), ptychopariids (Euloma) and shumardiids [Shumardia (Conophrys)], and the last record of conodonts belonging to the $P$. deltifer Zone (Serpagli et al., 2007). The immigration of shumardiids is also documented in the Borrachón Formation of the Iberian Chains (Schmitz, 1971; Josopait, 1972).

In summary, the immigration events described above do not seem to have a direct relationship with major relative sea-level fluctuations, although they were more numerous and implying more diversified faunas when they took place in transgressive trends. In fact, two of the major faunal turnovers (marking the bases of the Upper Cambrian and the Tremadocian P. geinitzi Zone) are included within the same transgression. The only exception is related to the progradation of the $\mathrm{La}$ Dentelle Formation (Tremadocian), which was succeeded by a distinct faunal turnover, biostratigraphically marked by the base of the Tremadocian Shumardia (C.) pusilla Zone.

\section{Palaeobiogeographic affinities}

The biogeographic distribution of latest Middle Cambrian and Late Cambrian trilobites supports brachiopod data indicating strong affinities between NW Gondwana (Mediterranean region), East Gondwana (North China/Korea, South China, Australia, and Antarctica) and Kazakhstania during the late Languedocian, which became significantly stronger during the Late Cambrian (Fig. 10). This major shift in palaeobiogeographic connections, which contrasts with the Leonian-Caesaraugustian-early Languedocian (Middle Cambrian) dominant distribution throughout the AcadoBaltic province (Álvaro et al., 1999), may suggest a significant change in oceanic circulation patterns throughout Gondwana, a process already suggested by Brock et al. (2000) and Álvaro et al. (2003a).

\subsection{Trilobites}

According to Álvaro et al. (2003a), Late Cambrian trilobite biofacies possibly occur in the Mediterranean region at only three stratigraphic levels: (i) the Idamean or Steptoean (Iberian Chains, Montagne Noire, and Morocco), characterized by aphelaspidoid morphologies; (ii) the 

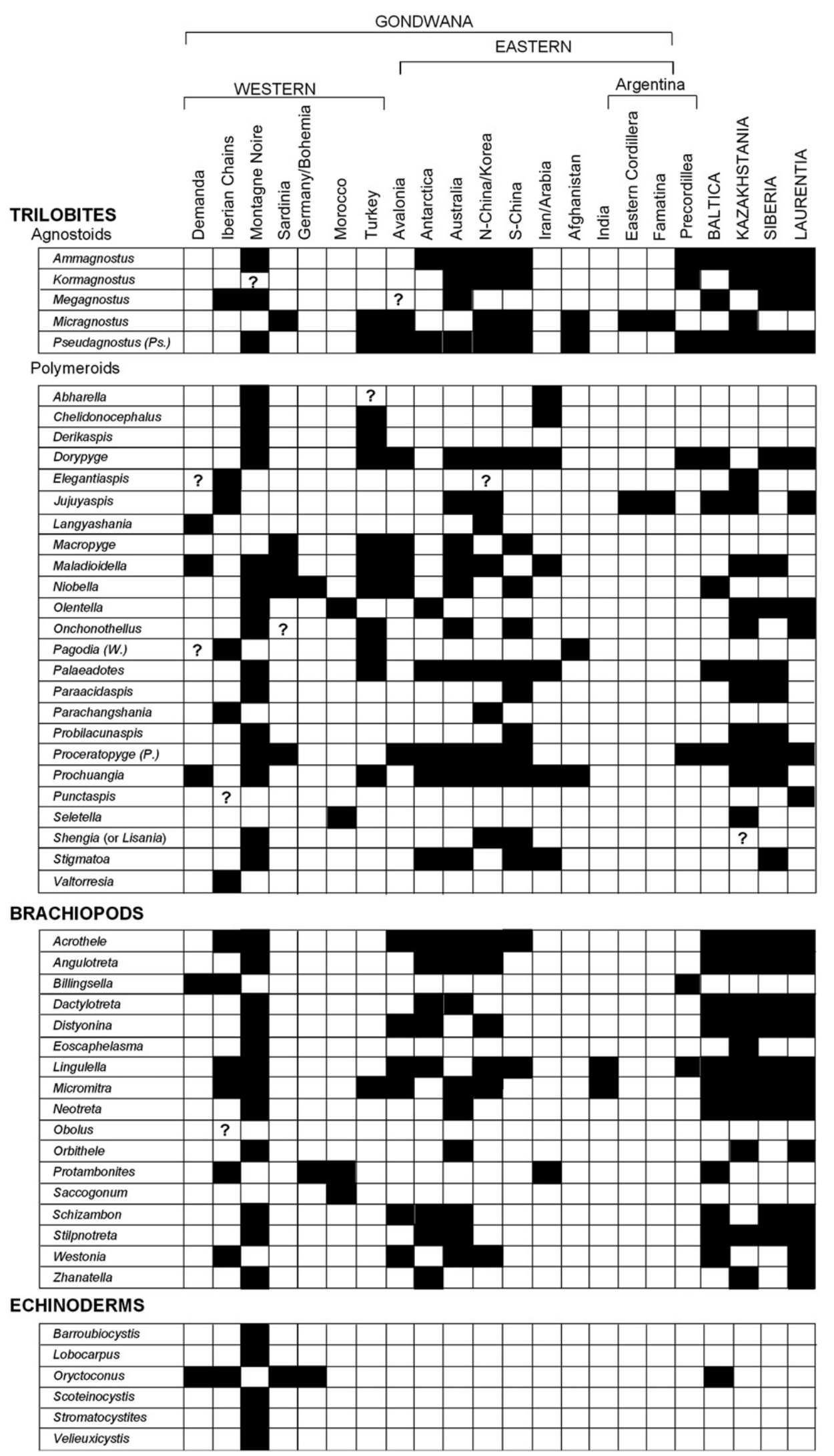

Fig. 10. Global distribution chart illustrating presence (black) and absence (white) of the late Languedocian (Middle Cambrian), Late Cambrian, and early Tremadocian trilobite genera reported in the text; based on papers reported in the text, and Dean (1982), Dean and Monod (1997), Dean et al. (1981, 1993), Shergold and Sdzuy (1984), and Rushton and Hughes (1996). 
Iverian or Sunwaptan (Demanda Mountains, Montagne Noire, Sardinia, and western Turkey), characterized by the occurrence of Maladioidella; and (iii) the Datsonian, of Cordylodus proavus Zone age. If the age of strata with Niobella, Macropyge, Pagodia (Wittekindtia), and Parakoldinioidia can be firmly established as of Cordylodus proavus Zone, then that biofacies becomes the third of latest Cambrian age. Some support for this assumption comes from conodonts recovered by Özgül and Gedik (1973) from the Sedissehir Formation in the Central Taurus Mountains, which by Australian standards are terminal Cambrian. Strata with Oryctoconus also support this assignment, since they occur in association with the Mediterranean 'Acerocare Regressive Event' associated with Tremadocian acritarchs and trilobites (Erdtmann, 1986; Nicoll et al., 1992; Loi et al., 1995, 1996).

As explained above, one of the typical Leonian-early Languedocian (Middle Cambrian) trilobite assemblage of the Acado-Baltic province sensu Sdzuy (1972), composed of conocoryphids, paradoxidids and solenopleurids, recorded, during the late Languedocian, the immigration of new (relatively) cosmopolitan invaders. Firstly, new genera, such as Abharella, Chelidonocephalus, Derikaspis and Dorypyge (King, 1937; Kushan, 1973; Wolfart, 1974; Fortey and Rushton, 1976; Dean, 1982; Courtessole et al., 1988; Álvaro et al., 1999), cooccurred with the aforementioned Middle Cambriantype families, but subsequently replaced them, and even co-existed with new Late Cambrian invaders.

Although the Asian affinity of some Late Cambrian trilobite invaders has been widely discussed in previous works (Courtessole et al., 1988; Álvaro et al., 1999, 2003a), an affinity subsequently expanded into an
Australo-Asian (East Gondwanan) influence by Shergold et al. (2000), the successive trilobite immigration events recorded in the western Mediterranean region show more widespread palaeobiogeographic affinities, not only reduced to peri-Gondwanan margins. Late Cambrian trilobites from the Iberian Chains and the Demanda Sierra exhibit both: (i) highly constrained palaeobiogeographic distributions [e.g., Elegantiaspis has been exclusively found in Kazakhstan, Pagodia (Wittenkindtia) in Afghanistan, and Langyashania in N-China/Korea]; and (ii) cosmopolitan distributions (e.g., Maladioiella and Prochuangia occur in Turkey, Iran, Avalonia, Antarctica/ Australia, N-China/Korea, S-China, Afghanistan, Kazakhstan, and Siberia). The Late Cambrian trilobites found in the Montagne Noire share the same pattern, with trilobite genera showing: (i) restricted distributions [e.g., Shengia or Lisania sensu Peng et al. (2004) occurs in South China]; (ii) intermediate distributions (Paraacidaspis and Probilacunaspis occur in South China, Kazakhstan and Siberia); and (iii) cosmopolitan distributions (e.g., Onchonotellus, Proceratopyge, Palaeadotes, Stigmatoa, and Olentella; see Fig. 10). It is also remarkable the co-occurrence of Selentella in Morocco and Kazakhstan (Ivshin, 1962).

A cluster analysis of the aforementioned palaeobiogeographic affinities, based exclusively on the trilobite genera found in the western Mediterranean region, documents closer relationships of the western Mediterranean region with, in decreasing importance, (i) Turkey, Avalonia, Australia/Antarctica, and South China; (ii) Laurentia, Precordillera, Baltica, Siberia, Kazakhstan, and North China/Korea; and finally (iii) Iran, Afghanistan, eastern Cordillera, and Famatina (Fig. 11).
TRILOBITES

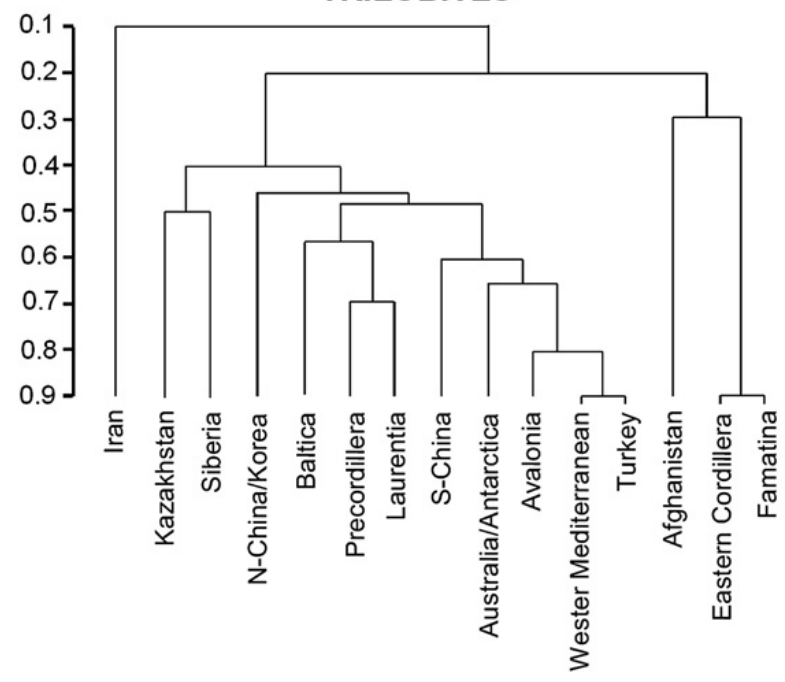

BRACHIOPODS

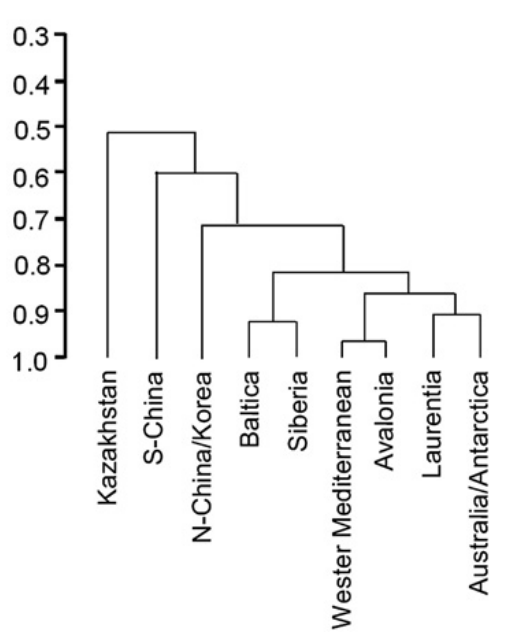

Fig. 11. Analysis of hierarchical Phi-Pearson similarity showing palaeobiogeographic affinities of the late Languedocian, Late Cambrian, and early Tremadocian trilobite and brachiopod genera found in the western Mediterranean region. 
Finally, trilobite endemism of Late Cambrian trilobite species is close to $85 \%$, which contrasts with the estimate close to $33-36 \%$ made by Vizcaïno and Álvaro (2003) for Tremadocian endemic species of the southern Montagne Noire [P. geinitzi and $S$. (C.) pusilla zones].

\subsection{Brachiopods}

The low-diversity patterns shown by the brachiopodbearing sandstones and shales of siliciclastic-dominated platforms contrasts with the abundance and diversity of late Languedocian and Late Cambrian linguliformean brachiopods preserved in limestones, which offer the possibility of testing palaeobiogeographic affinities. Some of the brachiopods reported from the southern Montagne Noire in Section 3.5 show cosmopolitan distributions, e.g., Acrothele, Dictyonina, Neotreta, Micromitra and Stilpnotreta. The pandemic affinity is also shared, in a single case, at the specific level: S. magna, originally described from the Middle Cambrian of Australia (Henderson and MacKinnon, 1981; Engelbretsen, 1996), was later found in Kazakhstan (Holmer et al., 2001) and Canada (Robson et al., 2003) (Fig. 10).

Dactylotreta occurs in the Middle and Upper Cambrian of many continents, such as Laurentia (USA, Greenland and western Newfoundland; Rowell and Henderson, 1978; Zell and Rowell, 1988; Robson and Pratt, 2001), Kazakhstan (Holmer et al., 2001), and eastern Gondwana (Antarctica and Australia; Rowell and Henderson, 1978; Popov in Solovjev et al., 1984; Henderson et al., 1992), and the Argentinian Precordillera (Holmer et al., 1999). The genus also occurs in the Tremadocian of Baltica (Sweden, Norway and southern Urals; Popov and Holmer, 1994; Holmer et al., 2001). Angulotreta shows a widespread distribution from Laurentia (USA and Canada; Zell and Rowell, 1988; Robson and Pratt, 2001) to low latitudes of eastern Gondwana (Australia; Henderson, 1974) and Kazakhstan (Holmer et al., 2001).

Other genera show more restricted palaeobiogeographic distributions: Eocaphelasma only occurs in the Upper Cambrian of Kazakhstan (Koneva et al., 1990; Popov and Holmer, 1994), and Zhanatella in the Upper Cambrian of Kazakhstan (Koneva, 1986; Popov and Ushatinskaya, 1992; Popov and Holmer, 1994), East Gondwana (Antarctica; Henderson et al., 1992), and Laurentia (USA; Popov and Ushatinskaya, 1992; Popov and Holmer, 1994).

All the aforementioned genera share subtropical to temperate palaeolatitudes. The late Middle Cambrian to Ordovician micromorphic linguliformean brachiopod associations are widely spread palaeogeographically.
However, in low latitudes they occur mainly in outershelf environments, whereas in Baltoscandia they may occur in relatively shallow-marine environments. Taking into account their nearshore-offshore distribution, their palaeobiogeographic distribution does not necessarily represent an argument for low thermal gradient between tropical and temperate latitudes (L. Popov, pers. comm., 2007).

A cluster analysis is also available in Fig. 11, although its result must take into account some biases that are more important in the study of phosphate-walled brachiopods than in that of trilobites. Published works on Late Cambrian brachiopods directly reflect the abundance (or presence/absence) of limestones because valves are currently studied after etching. As a result, the method of study of tridimensionally preserved brachiopod valves directly controls the quantity and quality of works on brachiopod systematics. As in the case of trilobites, three palaeobiogeographic influences can be identified, in order of decreasing importance: (i) Avalonia, Laurentia, and Australia/Antarctica; (ii) Baltica, Siberia, and North China/Korea; and (iii) South China and Kazakhstan. The differences of palaeobiogeographic affinities between trilobites and brachiopods may also be associated with the different capacity of pelagic transport of their respective larvae.

The linguliformean brachiopods found in the limestones of the Val d'Homs Formation share with the aforementioned trilobites a distinct character: a high degree of endemism. Although González-Gómez $(2005 a, b)$ described 17 species in the latest MiddleUpper Cambrian of the southern Montagne Noire, only two of them are known outside the Montagne Noire; the rest is either described in open nomenclature or erected as new species.

\subsection{Echinoderms}

Echinoderms are extremely rare in the Upper Cambrian of the western Mediterranean region. Their disarticulated ossicles are commonly associated with trilobite and brachiopod coquinas, but their determination is difficult. There are two exceptions: the endemic fauna of the Val d'Homs Formation in the southern Montagne Noire and the Oryctoconus holdfasts. In the Barroubio valley (Pardailhan nappe), numerous limestone nodules embedded in siltstones of the Val d'Homs Formation have yielded an echinoderm assemblage, composed of four endemic genera: the phyllocystid? (cornute) Lobocarpus, the glyptocystitids (cystoid) Barroubiocystis and Velieuxicystis, and the stromatocystitid? Scoteinocystis (Ubaghs, 1998) (Fig. 10). 
The pelmatozoan holdfast $O$. lobatus is herewith used as a biostratigraphically useful taxon, due to its cooccurrence with early Tremadocian trilobites and acritarchs in Sardinia, the Cantabrian Zone, the Demanda Sierra, and the Iberian Chains (Álvaro and Colchen, 2002), although its first appearance could be latest Late Cambrian in age. Another species, Oryctoconus dorecki, is known from the Tremadocian of the Leimitz Shales (Germany; Sdzuy, 1955), and some uncertain Early Ordovician echinoderm debris from Finmark (Norway), described originally by Erdtmann et al. (1984), were assigned to Oryctoconus by Berg-Madsen (1986).

\section{Was the drift of West Gondwana unequal?}

Both the Cambrian and Early Ordovician global palaeogeographic models of NW Gondwana have been greatly improved in the last decade due to analyses on palaeomagnetism, palaeobiogeography and climatically controlled facies. The western Gondwanan margin, which spread across South America, NW Africa, Avalonia, and the Mediterranean region, virtually suffered the same South-poleward drifting during the Cambrian and Early Ordovician. One methodological problem to document graphically this drift is the kind of global palaeogeographic reconstructions, as Cambrian workers commonly use equatorial perspectives and Ordovician ones polar perspectives. The latter are useful for discussing palaeoclimatic implications and are used in this work (Fig. 12).

One unresolved problem is the setting of the South Pole in Late Cambrian-Tremadocian palaeogeographic reconstructions. In some of them (e.g., Cocks and Torsvik, 2002; Fortey and Cocks, 2003), the South Pole is situated close to southwestern Europe, so that the Iberian Peninsula and the Montagne Noire are inside the $60^{\circ} \mathrm{S}$ polar circle. However, three key data seem to evidence a temperate setting for the western Mediterranean region across the Late Cambrian-Tremadocian. The first is the setting of this region across the LowerMiddle Cambrian transition. Although the distribution of climatically restricted facies and lithologies is related to Recent latitudinal belts controlled by the modern 'icehouse' situation, and not to the Cambrian 'greenhouse' time (Berner, 1990), it offers key information to estimate relative rates of drifting. This area seemingly crossed the $30^{\circ} \mathrm{S}$ arid subtropical circle at this time, as reported by a peak in evaporitic and carbonate deposition (Álvaro et al., 2000, 2003a). Obviously, the southward drifting rate could not accelerate during a short time span of ca. 12 m.y. (Middle Cambrian) crossing $30-40^{\circ}$ of latitude, and subsequently returning to previous rates.
Another argument is the presence of Late CambrianTremadocian active carbonate factories in the southern Montagne Noire (Val d'Homs and Mounio formations; Álvaro et al., 2003b; Vizcaïno and Álvaro, 2003). And the third argument is yielded by palaeomagnetic data: Nysæther et al. (2002) located the Cabrières Wildflysch of the Montagne Noire (southern France) at higher southerly latitudes $\left(68^{\circ}+17 /-15\right)$ during Middle Ordovician times (Llanvirn to early Caradoc, ca. 470-458 Ma). As a result, the western Mediterranean region probably occupied med (temperate-water) latitudes, and not subpolar settings, during the Late Cambrian and Tremadocian.

\section{Concluding remarks}

The identification of Upper Cambrian strata in the western Mediterranean region is dramatically constrained by the record of erosive unconformities and condensed units. In the Moroccan Anti-Atlas, Cantabrian Zone, Montagne Noire and SW Sardinia, a diachronous Late Cambrian-to-Middle Ordovician unconformity truncated large areas of their platforms. These hiatii can be related to a phase of neighbouring rifting (further North) and concomitant erosion on southern rift shoulders. The rifting is currently related to the opening of the Rheic Ocean, widely believed to have formed in the Late Cambrian-Early Ordovician as a result of the drift of peri-Gondwanan terranes from the northwestern Gondwanan margin.

The Upper Cambrian of the southern Montagne Noire and the Iberian Chains lacks significative gaps. There, Upper Cambrian strata are bracketed by two major regressive trends, which are topped by: (i) an uppermost Middle Cambrian discontinuity related to the progradation of back-shoal tidal-flat environments (lower part of the La Gardie and Valdeorea-Torcas formations, respectively); and (ii) an Upper Cambrianlower Tremadocian discontinuity related to the progradation of foreshore to shoreface, shoal complexes (La Dentelle and Valconchán formations). In this context, the Upper Cambrian sedimentation took place in a transgressive-dominated depositional system, with common offshore deposits and clayey substrates (upper part of the La Gardie/Val d'Homs and Valtorres formations).

The Late Cambrian is also associated with: (i) the record of volcanic activity in the Cantabrian Zone and the northern Montagne Noire; and (ii) widespread development of tectonic instability. The latter is documented in the western Mediterranean region by episodic development of palaeotopographies and record of slope-related facies associations. The reported basins and platforms occupied temperate-water latitudes, 


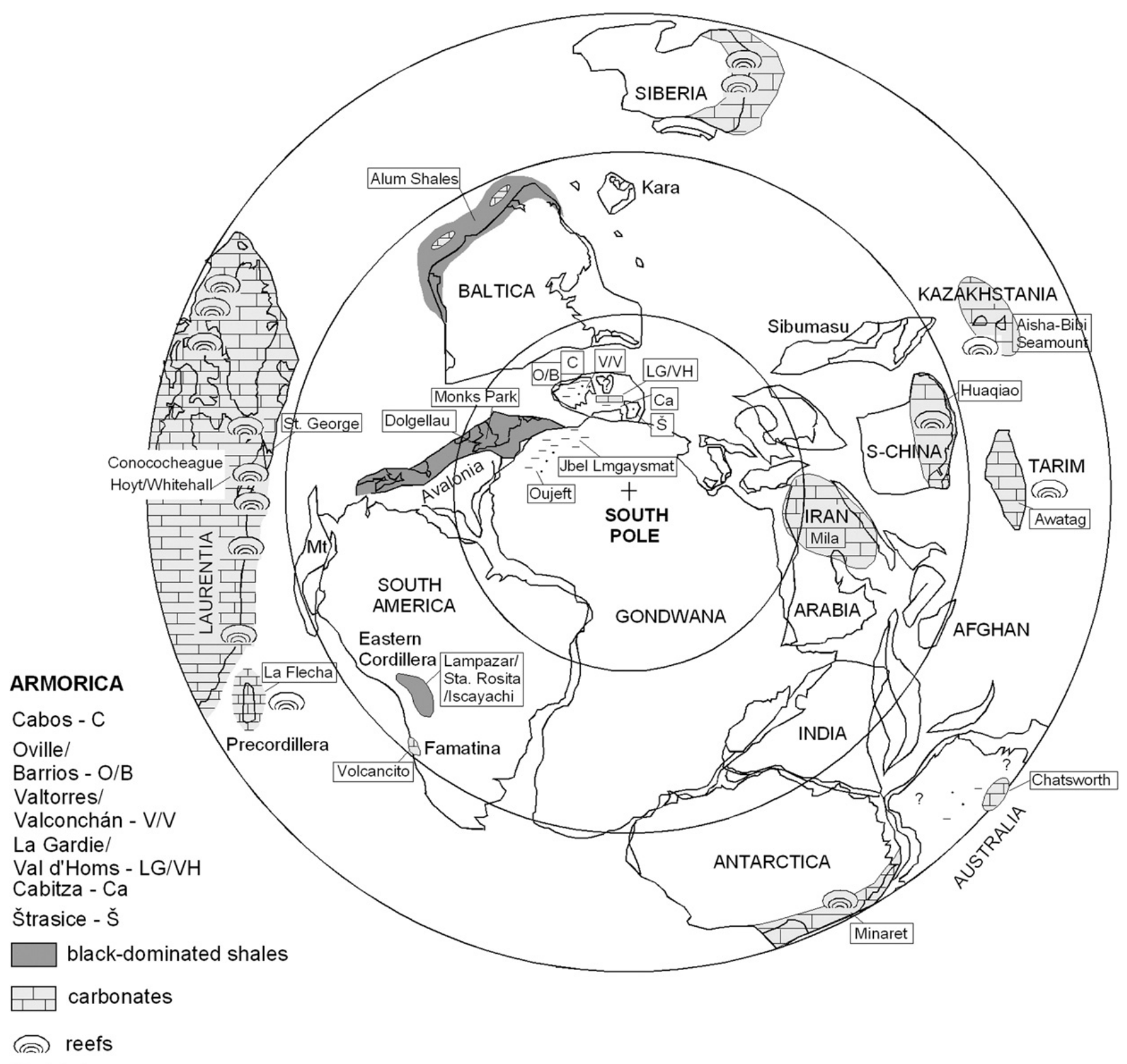

Mt - Mexican terranes

Fig. 12. Global palaeogeographic reconstruction (after Cocks and Torsvik, 2002; Rowland and Shapiro, 2002; Fortey and Cocks, 2003; and papers reported in this work) with setting of subtropical- and temperate-water carbonate factories, terrigenous belts and black shales. Note the anomalous position of the carbonate factories related to the Montagne Noire.

where carbonate factories were episodically active in the southern-Montagne-Noire platform, which represents the northernmost part of the study region.

Several immigration events are recognized throughout the latest Middle Cambrian, Late Cambrian and Tremadocian. The trilobites show a stepwise replacement of Acado-Baltic-type families (e.g., the conocoryphidparadoxidid-solenopleurid assemblage) characterized by: (i) a late Languedocian (latest Middle Cambrian) cooccurrence of Middle Cambrian trilobite families with the first anomocarid, dorypygid and proasaphiscid invaders; (ii) a Late Cambrian (lower Peltura Zone) immigration replacing previous faunas, composed of trilobites (aphelaspidids, catillicephalids, ceratopygids, damesellids, eulomids, idahoiids, linchakephalids, lisariids, onchonotinids, and pagodiids), linguliformean brachiopods (acrotretids, obolids, scaphelasmatids, siphonotretids, and zhanatellids), echinoderms (mitrates, glyptocystitid cystoids, and stromatocystoids) and conodonts; (iii) and the subsequent input of new trilobites (asaphids, calymenids, catillicephalids, nileids and remopleurid), which marks the base of the $P$. geinitzi Zone, associated with pelmatozoan holdfasts (Oryctoconus), and late Tremadocian conodonts ( $P$. deltifer Zone). These immigration 
events took place associated with a broad transgression, so that they were not affected by relative sea-level fluctuations, and are useful for bounding biostratigraphic units.

The biogeographic distribution of Late Cambrian trilobites supports brachiopod data indicating strong affinities between NW Gondwana (Mediterranean region), East Gondwana (North China/Korea, South China, Australia, and Antarctica) and Kazakhstania during the late Languedocian, which became significantly stronger during the Late Cambrian. This major shift may suggest modification in oceanic circulation patterns throughout Gondwana across the Middle-Late Cambrian transition.

\section{Acknowledgements}

This paper is a contribution to IGCP projects 497 'The Rheic Ocean: its origin, evolution and correlatives' and 503 'Ordovician Palaeogeography and Palaeoclimate'. Financial support has been obtained from project CGL 2006-13533 of the Spanish 'Ministerio de Educación y Ciencia'. We deeply appreciate the peer revisions made by E. Landing and L. Popov.

\section{References}

Ahlberg, P., 1998. Cambrian shelly faunas and biostratigraphy of Scandinavia. In: Ahlberg, P. (Ed.), Guide to Excursions in Scånia and Västergötland, Southern Sweden. IV Field Conference of the Cambrian Stage Subdivision Working Group, International Subcommission on Cambrian Stratigraphy. Lund Publications in Geology, vol. 141, pp. 5-9.

Ahlberg, P., 2003. Trilobites and intercontinental tie points in the Upper Cambrian of Scandinavia. Geologica Acta 1, 127-134.

Albani, R., Di Milia, A., Minzoni, N., Tongiorgi, M., 1985. Nuovi dati palinologici e considerazioni geologiche sull'età delle Arenarie di Solanas (Cambro-Ordoviciano, Sardegna Centrale). Atti della Società Toscana di Scienze Naturali, Memorie, serie A, 91, 1-20.

Albani, R., Massa, D., Tongiorgi, M., 1991. Palynostratigraphy (Acritarchs) of some Cambrian beds from the Rhadames (Ghadamis) Basin (Western Libya-Southern Tunisia). Bollettino della Società Paleontologica Italiana 30, 255-280.

Albani, R., Bagnoli, G., Bernárdez, E., Gutiérrez-Marco, J.C., Ribecai, C., 2006. Late Cambrian acritarchs from the "Túnel del Fabar", Cantabrian Zone, N Spain. Review of Palaeobotany and Palynology $139,41-52$.

Álvaro, J.J., 1995. Propuesta de una nueva unidad litoestratigráfica para el Cámbrico Medio-Superior de las Cadenas Ibéricas (NE España): el Grupo Acón. Boletín de la Real Sociedad Española de Historia Natural (Sección Geológica) 90, 95-106.

Álvaro, J.J., Vennin, E., 1996a. The Middle-Upper Cambrian transition in the Iberian Chains (NE Spain): an integrated approach. Rivista Italiana di Paleontologia e Stratigrafia 102, 341-352.

Álvaro, J.J., Vennin, E., 1996b. Tectonic control on Cambrian sedimentation in south-western Europe. Eclogae Geologica Helvetiae 89, 935-948.
Álvaro, J.J., Vennin, E., 2001. Benthic marine communities recorded in the Cambrian Iberian platform, NE Spain. Palaeontographica, Abteilung A, Paläozoologie, Stratigraphie 262, 1-23.

Álvaro, J.J., Colchen, M., 2002. Earliest Ordovician pelmatozoan holdfasts from western Europe: the Oryctoconus problem revisited. Eclogae Geologica Helvetiae 95, 451-459.

Álvaro, J.J., Vizcaïno, D., Vennin, E., 1999. Trilobite diversity patterns in the Middle Cambrian of southwestern Europe: a comparative study. Palaeogeography, Palaeoclimatology, Palaeoecology 151, 241-254.

Álvaro, J.J., Rouchy, J.M., Bechstädt, T., Boucot, A., Boyer, F., Debrenne, F., Moreno-Eiris, E., Perejón, A., Vennin, E., 2000. Evaporitic constraints on the southward drifting of the western Gondwana margin during Early Cambrian times. Palaeogeography, Palaeoclimatology, Palaeoecology 160, 105-122.

Álvaro, J.J., Lefebvre, B., Shergold, J.H., Vizcaïno, D., 2001. The Middle-Upper Cambrian of the southern Montagne Noire. Annales de la Société Géologique du Nord ( $2^{\mathrm{e}}$ série) 8, 205-211.

Álvaro, J.J., Elicki, O., Geyer, G., Rushton, A.W.A., Shergold, J.H., 2003a. Palaeogeographical controls on the Cambrian trilobite immigration and evolutionary patterns reported in the western Gondwana margin. Palaeogeography, Palaeoclimatology, Palaeoecology 195, 5-35.

Álvaro, J.J., González-Gómez, C., Vizcaïno, D., 2003b. Paleogeographic patterns of the Cambrian-Ordovician transition in the southern Montagne Noire (France): preliminary results. Bulletin de la Société géologique de France 174 (3), 23-31.

Álvaro, J.J., Ferretti, A., González-Gómez, C., Pierre, C., Serpagli, E., Subías, I., Vecoli, M., Vizcaïno, D., 2005. An updated Furongian stratigraphic framework for southwestern Europe. Acta Micropalaeontologica Sinica 22, 3-5 (Supplement).

Aramburu, C., 1989. El Cámbrico-Ordovícico de la Zona Cantábrica (N. O. de España). Unpublished PhD Thesis, Oviedo University, 530 p.

Aramburu, C., García-Ramos, C., 1988. Presencia de la discontinuidad sárdica en la Zona Cantábrica. Geogaceta 5, 11-13.

Aramburu, C., García-Ramos, C., 1993. La sedimentación cambroordovícica en la Zona Cantábrica (NO de España). Trabajos de Geología (Universidad de Oviedo) 19, 45-73.

Aramburu, C., Truyols, J., Arbizu, M., Méndez-Bedia, I., Zamarreño, I., García-Ramos, J.C., Suárez de Centi, C., Valenzuela, M., 1992. El Paleozoico Inferior de la Zona Cantábrica. In: Gutiérrez-Marco, J.C., Saavedra, J., Rábano, I. (Eds.), Paleozoico Inferior de IberoAmérica. UNEX Press, Mérida, pp. 397-422.

Aramburu, C., Méndez-Bedia, I., Arbizu, M., García-López, S., 2004. Zona Cantábrica. Estratigrafía. La secuencia preorogénica. In: Vera, J. (Ed.), Geología de España, Sociedad Geológica de España and Instituto Geológico y Minero de España, Madrid, pp. 27-34.

Artyushkov, E.A., Lindström, M., Popov, L.E., 2000. Relative sea-level changes in Baltoscandia in the Cambrian and Early Ordovician: the predominance of tectonic factors and the absence of large scale eustatic fluctuations. Tectonophysics 320, 375-407.

Babin, C., Hammann, W., 2001. Une nouvelle espèce de Modiolopsis (Bivalvia) dans l'Arénig (Ordovicien inférieur) de Daroca (Aragon, Espagne): réflexions sur la denture des bivalves primitifs. Revista Española de Paleontología 16, 269-282.

Baldwin, C.T., 1977. The stratigraphy and facies associations of trace fossils in some Cambrian and Ordovician rocks of northwestern Spain. In: Crimes, T.P., Harper, J.C. (Eds.), Trace Fossils 2. Geological Journal, Special Issue, vol. 9, pp. 9-40.

Baldwin, C.T., 1978. A comparison of the stratigraphy and depositional processes in the Cambro-Ordovician rocks of the Cantabrian and West Asturian-Leonese Zones, NW Spain. In: 
Julivert, M. (Ed.), Geología de la parte N del Macizo Ibérico, Tomo I Homenaje Parga-Pondal. Del Castro, La Coruña, pp. 43-70.

Barca, S., Cocozza, R., del Rio, M., Pillola, G.L., Pittau Demelia, P., 1987. Datation de l'Ordovicien inférieur par Dictyonema flabelliforme et acritarches dans la partie supérieur de la formation «Cambrienne » de Cabitza (SW de la Sardaigne, Italie): conséquences géodynamiques. Comptes Rendus de l'Académie des Sciences 305, 1109-1111.

Berg-Madsen, V., 1986. Middle Cambrian cystoid (sensu lato) stem columnals from Bornholm, Denmark. Lethaia 19, 67-80.

Berner, R.A., 1990. Atmospheric carbon dioxide over Phanerozoic time. Science 249, 1382-1386.

Brasier, M.D., 1993. Towards a carbon isotope stratigraphy of the Cambrian System: potential of the Great Basin succession. Geological Society of London, Special Publication, vol. 70, pp. 341-350.

Briggs, J.C., 1995. Global biogeography. Developments on Palaeontology and Stratigraphy 14, 1-454.

Brock, G.A., Engelbretsen, M.J., Jago, J.B., Kruse, P.D., Laurie, J.R., Shergold, J.H., Shi, G.R., Sorauf, J.E., 2000. Palaeobiogeographic affinities of Australian Cambrian faunas. Memoir of the Association of Australasian Palaeontologists 23, 1-61.

Burkhard, M., Caritg, S., Helg, U., Robert-Charrue, C., Soulaimani, A., 2006. Tectonics of the Anti-Atlas of Morocco. Comptes Rendus Geoscience 338, 11-24.

Cabanis, B., 1986. Identification des séries magmatiques dans les socles métamorphiques, sur la base de critères géologiques, pétrologiques et géochimiques. Unpublished $\mathrm{PhD}$ Thesis, University of Paris VI, $682 \mathrm{p}$.

Calvet, P., Lapierre, H., Charvet, J., 1988. Diversité du volcanisme Ordovicien dans la région de Pierrefitte (Hautes-Pyrénées): rhyolites calcoalcalines et basaltes alcalins. Comptes Rendus de l'Académie des Sciences 307, 805-812.

Chang, W.T., 1988. Cambrian System in eastern Asia (correlation chart and explanatory notes). International Union of Geological Sciences Publication 24, 1-81.

Chen, Jun-Yuan, Qian, Yi-Yuan, Zhang, Jun-Ming, Lin, Yao-Kun, Yin, Lei-Ming, Wang, Zhi-Hao, Wang, Zong-Zi, Yang, Jie-Dong, Wang, Ying-Xi, 1988. The recommended Cambrian-Ordovician global boundary stratotype of the Xiaoyangqiao section (Dayangcha, Jilin Province), China. Geological Magazine 125, 415-444.

Cocks, L.R.M., Torsvik, T.H., 2002. Earth geography from 500 to 400 million years ago. A faunal and palaeomagnetic review. Journal of the Geological Society, London 159, 631-644.

Colchen, M., 1967. Sur la présence du Cambrien supérieur à Prochuangia et à Chuangia dans la Sierra de la Demanda (Logroño), Espagne. Comptes Rendus de l'Académie des Sciences 264, $1687-1690$

Colchen, M., 1974. Géologie de la Sierra de la Demanda. BurgosLogroño (Espagne). Memorias del Instituto Geológico y Minero de España 85, 1-436.

Colchen, M., Havlíček, V., 1968. Le niveau à Billingsella cf. lingulaeformis Nikitin du Cambrien de la Sierra de la Demanda. Bulletin de la Société Géologique de France ( $7^{\mathrm{e}}$ Série) 10, 133-137.

Colchen, M., Ubaghs, G.P., 1969. Sur les restes d'Echinodermes (?) du Cambro-Ordovicien de la Sierra de la Demanda (Burgos-Logroño, Espagne). Bulletin de la Société géologique de France ( $7^{\mathrm{e}}$ Série) 11, 649-654.

Cooper, R.A., Nowlan, G.S., 1999. Proposed global stratotype section and point for the base of the Ordovician System. International Working Group on the Cambrian-Ordovician Boundary, March 1999, pp. 1-28.
Cooper, R.A., Jago, J.B., Begg, J.G., 1996. Cambrian trilobites from northern Victoria Land, Antarctica, and their stratigraphic implications. New Zealand Journal of Geology and Geophysics 39, 363-387.

Courtessole, R., Pillet, J., Vizcaïno, D., 1988. Stratigraphie et paléontologie du Cambrien moyen gréseux de la Montagne Noire (versant méridional). Mémoires de la Société d'Etudes Scientiques de l'Aude. 55 pp.

Crimes, T.P., Marcos, A., 1976. Trilobite traces and the age of the lowest part of the Ordovician reference section for NW Spain. Geological Magazine 113, 350-356.

Crossley, R., McDougall, N., 1998. Lower Palaeozoic reservoirs of North Africa. In: MacGregor, D.S., Moddy, R.T.J., Clark Lowes, D.D. (Eds.), Petroleum Geology of North Africa. Geological Society of London, Special Publication, vol. 132, pp. 157-166.

Davidek, K.L., Landing, E., Bowring, S.A., Westrop, S.R., Rushton, A.W.A., Fortey, R.A., Adrain, J., 1998. New uppermost Cambrian $\mathrm{U}-\mathrm{Pb}$ date from Avalonian Wales and age of the Cambrian-Ordovician boundary. Geological Magazine 133, 303-309.

Dean, W.T., 1982. Middle Cambrian trilobites from the Sosink Formation, Derik-Mardin district, south-eastern Turkey. Bulletin of the British Museum (Natural History), Geological Series, vol. 36, pp. 71-81.

Dean, W.T., Monod, O., 1997. Cambrian development of the Gondwanaland margin in Southeastern Turkey. Turkish Association of Petroleum Geologists, Special Publication, vol. 3, pp. 61-74.

Dean, W.T., Monod, O., Perinçek, D., 1981. Correlation of the Cambrian and Ordovician rocks in southeastern Turkey. Petroleum activities at the 100th year (100 Yilda Petrol Faaliyeti). T.C. Petrol İsleri Genel Müdürlüğü Dergisi (Ankara), vol. 25, pp. 269-300.

Dean, W.T., Martin, F., Monod, O., Gül, M.A., Bozdoğan, N., Özgül, N., 1993. Early Palaeozoic evolution of the Gondwanaland margin in the western and central Taurids, Turkey. In: Turgut, S. (Ed.), Tectonics and Hydrocarbon Potential of Anatolia and Surrounding Regions. Ozan Sunğurlu Symposium Proceedings, November 1991, Ankara, pp. 262-272.

Deloule, E., Alexandrov, P., Cheilletz, B., Laumonier, B., Barbey, P., 2002. In situ $\mathrm{U}-\mathrm{Pb}$ zircon ages for early Ordovician magmatism in the eastern Pyrenees, France: the Canigou orthogneisses. International Journal of Earth Sciences 91, 398-405.

Denison, R.E., Koepnick, R.B., Burke, W.H., Hetherington, E.A., 1998. Construction of the Cambrian and Ordovician seawater ${ }^{87} \mathrm{Sr} /{ }^{86} \mathrm{Sr}$ curve. Chemical Geology 152, 325-340.

Destombes, J., 1989. Notice explicative de la carte géologique du Maroc au 200.000 'Zagora-Coude du Drâa' (Anti-Atlas central). Notes et Mémoires du Service Géologique du Maroc 273, 1-82 (2nd ed., 2003, rapport interne).

Destombes, J., Feist, R., 1987. Découverte du Cambrien supérieur en Afrique (Anti-Atlas, Central Maroc). Comptes Rendus de l'Académie des Sciences ( $2^{\mathrm{e}}$ Série) 304, 719-724.

Destombes, J., Hollard, H., Willefert, S., 1985. Lower Palaeozoic rocks of Morocco. In: Holland, C.H. (Ed.), Lower Palaeozoic Rocks of the World. Lower Palaeozoic of North-Western and West Central Africa, vol. 4. John Wiley and Sons, Chichester, pp. 157-184.

Di Milia, A., 1991. Upper Cambrian acritarchs from the Solanas Formation, Central Sardinia, Italy. Bollettino della Società Paleontologica Italiana 30, 127-152.

Di Milia, A., Tongiorgi, M., Albani, R., 1993. Acritarchs findings in Early Paleozoic, low-grade metasediments of Sardinia (Italy). Revista Española de Micropaleontología 8, 170-176. 
Dong, Xiping, Bergström, S.M., 2001. Middle and Upper Cambrian protoconodonts and paraconodonts from Hunan, South China. Palaeontology 44, 949-985.

Eisenack, A., 1958. Tasmanites Newton 1875 und Leiosphaeridia n. g. als Gattungen der Hystrichosphaeridea. Palaeontographica. Abteilung A, Paläozoologie, Stratigraphie 110, 1-19.

Encarnacion, J., Rowell, A.J., Grunow, A.M., 1999. A U-Pb age for the Cambrian Taylor Formation, Antarctica: implications for the Cambrian timescale. Journal of Geology 107, 497-504.

Engelbretsen, M.J., 1996. Middle Cambrian lingulate brachiopods from the Murrawong Creek Formation, Northeastern New South Wales. Historical Biology 11, 69-99.

Erdtmann, B.D., 1986. Early Ordovician eustatic cycles and their bearing on punctuations in early nematophorid (planctic) graptolite evolution. Lectures and Notes in Earth Sciences 8, 139-152.

Erdtmann, B.D., 1988. The earliest Ordovician nematophorid graptolites: taxonomy and correlation. Geological Magazine 125, $327-348$

Erdtmann, B.D., Henningsmoen, G., Welsch, M., Windolph, M.L., 1984. Fossiler frå Digermulhalvøya. Ottar 146, 10-30.

Ergaliev, G.K., 1990. Kyrshabakty stratotype section of the Middle and Upper Cambrian. Guide-Book, The Third International Symposium on the Cambrian System. Excursion 2. International Subcommission on the Cambrian System; International Commission on the Stratigraphy of the International Union of Geological Sciences. Academy of Sciences of the Kazakh SSR, Alma-Ata, 27-37.

Etxebarría, M., Chalot-Prat, F., Apraiz, A., Eguíluz, L., 2006. Birth of a volcanic passive margin in Cambrian time: rift paleogeography of the Ossa-Morena Zone, SW Spain. Precambrian Research 147, 366-386.

Feist, R., Courtessole, R., 1984. Découverte de Cambrien supérieur à trilobites de type est-asiatique dans la Montagne Noire (France méridionale). Comptes Rendus de l'Académie des Sciences ( $2^{\mathrm{e}}$ Série) $298,177-182$.

Fombella, M.A., 1986. El tránsito Cámbrico-Ordovícico, palinología y diacronismo, provincia de León, NO de España. Revista Española de Micropaleontología 18, 165-455.

Fombella, M.A., 1987. Resemblances and differences between the palynological associations of Upper Cambrian age in the NW of Spain (Vozmediano) and North of Africa. Revue de Micropaléontologie 30, 111-116.

Fortey, R.A., 1994. Late Cambrian trilobites from the Sultanate of Oman. Neues Jahrbuch für Geologie und Paläontologie, Abhandlungen 194, 25-53.

Fortey, R.A., Cocks, L.R.M., 2003. Palaeontological evidence bearing on global Ordovician-Silurian continental reconstructions. EarthScience Reviews 61, 245-307.

Fortey, R.A., Rushton, A.W.A., 1976. Chelidonocephalus trilobite fauna from the Cambrian of Iran. Bulletin of the British Museum, Natural History, Geological Series 27, 321-340.

Fortey, R.A., Harper, D.A.T., Ingham, J.K., Owen, A.W., Rushton, A.W.A., 1995. A revision of Ordovician series and stages from the historical type area. Geological Magazine 132, 15-30.

García-Ramos, J.C., Aramburu, C., Brime, C., 1984. Kaolinite tonstein of volcanics ash origin in the Lower Ordovician of the Cantabrian Mountains (NW Spain). Trabajos de Geología, vol. 14. Universidad de Oviedo, pp. 27-33.

Gasquet, D., Levresse, G., Cheilletz, A., Rachid Azizi-Samiz, M., Mouttaqi, A., 2005. Contribution to a geodynamic reconstruction of the Anti-Atlas (Morocco) during Pan-African times with the emphasis on inversion tectonics and metallogenic activity at the
Precambrian-Cambrian transition. Precambrian Research 140, 157-182.

Geyer, G., Shergold, J., 2000. The quest for internationally recognized divisions of Cambrian time. Episodes 23, 188-195.

Geyer, G., Landing, E., Shergold, J.H., 2002. New data on the Upper Cambrian of Morocco. VII Conference of the Cambrian Stage Subdivision Working Group (ISCS), Caunes-Minervois. Programme and Abstracts, vol. 18.

Gietelink, G., 1973. Sedimentology of a linear prograding coastline followed by three high-destructive delta complexes (CambroOrdovician, Cantabrian Mountains, NW Spain). Leidse Geologische Mededelingen 49, 125-144.

González-Gómez, C., 2005a. Linguliformean brachiopods of the Middle-Upper Cambrian transition from the Val d'Homs Formation, southern Montagne Noire, France. Journal of Paleontology 79, $29-47$.

González-Gómez, C., 2005b. Braquiópodos linguliformes de la transición Cambro-Ordovícica en la vertiente meridional de la Montaña Negra (Languedoc, Francia). Unpublished PhD Thesis, Zaragoza University, $132 \mathrm{p}$.

Guérangé-Lozes, J., Burg, J.P., 1990. Les nappes varisques du sudouest du Massif central. Géologie de la France 3-4, 71-106.

Gutiérrez-Marco, J.C., Herranz, P., Pieren, A., Rábano, I., Sarmiento, G.N., de San José, M.A., Barnolas, A., Villas, E., 2004. El margen pasivo ordovícico. In: Vera, J.A. (Ed.), Geología de España. SGEIGME, Madrid, pp. 472-475.

Hall, J., 1858. Descriptions of Canadian graptolites. Geological Survey of Canada, Report for 1857, pp. 111-145.

Hall, J., 1865. Graptolites of the Quebec Group. Geological Survey of Canada, Canadian organic remains, pp. 1-151. dec. 2.

Havlíček, V., 1971. Brachiopodes de l'Ordovicien du Maroc. Notes et Mémoires du Service géologique du Maroc 120, 1-135.

Havlíček, V., Josopait, V., 1972. Articulate brachiopods from the Iberian Chains, northeast Spain (Middle Cambrian-Upper Cambrian-Tremadoc). Neues Jahrbuch für Geologie und Paläontologie, Abhandlungen 140, 328-353.

Heinz, W., Loeschke, J., Vaura, G., 1985. Phreatomagmatic volcanism during the Ordovician of the Cantabrian Mountains. Geologische Rundschau 74, 623-639.

Helbing, H., Tiepolo, M., 2005. Age determination of Ordovician magmatism in NE Sardinia and its bearing on Variscan basement evolution. Journal of the Geological Society, London 162, 689-700.

Henderson, R.A., 1974. Shell adaptation in acrothelid brachiopods to settlement on a soft substrate. Lethaia 7, 57-61.

Henderson, R.A., MacKinnon, D.I., 1981. New Cambrian inarticulate brachiopods from Australia and the age of the Tasman Formation. Alcheringa 5, 289-309.

Henderson, R.A., Debrenne, F., Rowell, A.J., Webers, G.F., 1991. Brachiopods, archaeocyathids, and Pelmatozoa from the Minaret Fomation of the Ellsworth Mountains, West Antarctica. Geological Society of America, Memoir, vol. 170, pp. 249-267.

Holmer, L.E., Popov, L.E., Lehnert, O., 1999. Cambrian phosphatic brachiopods from the Precordillera of western Argentina. Geologiska Föreningens i Stockholm Förhandlingar 121, 227-242.

Holmer, L.E., Popov, L.E., Koneva, S.P., Bassett, M.G., 2001. Cambrian-Early Ordovician brachiopods from Malyi Karatau, the western Balkhash region, and Tien Shan, Central Asia. Special Papers in Palaeontology 65, 1-180.

Ivshin, N.K., 1962. Verkhnekembriskie trilobity Kazakhstana, Chast 2. Seletinskiy gorizont Kuyandinskogo yarusa tsentral'nogo Kazakhstana. Izdatel'stvo Institut Geologicheskikh Nauk, Akademiya Nauk Kazakhskoy SSR, Alma Ata, pp. 1-412. 
Jago, J.B., Brown, A.V., 1992. Early Idamean (Late Cambrian) agnostoid trilobites from the Huskisson River, Tasmania. Papers and Proceedings of the Royal Society of Tasmania 126, 59-65.

Josopait, V., 1972. Das Kambrium und das Tremadoc von Ateca (Westliche Iberischen Ketten, NE-Spanien). Münstersche Forschungen zur Geologie und Paläontologie 23, 1-121.

King, W.B.R., 1937. Cambrian trilobites from Iran (Persia). Palaeontographica Indica (Geological Survey of India) 22, 1-22.

Kolb, S., Wolf, R., 1979. Distribution of Cruziana in the Lower Ordovician sequence of Celtiberia (NE Spain) with a revision of the Cruziana rugosa-group. Neues Jahrbuch für Geologie und Paläontologie, Monatshefte 8, 457-474.

Koneva, S.P., 1986. Novoe semeistvo kembriiskikh bezzambovykh brackhiopod [A new family of Cambrian inarticulate brachiopods]. Paleontologicheskii Zhurnal 3, 47-56.

Koneva, S.P., Popov, L.E., Ushatinskaya, G.T., Esakova, N.V., 1990. Bezzamkovye brakiopody (akrotretidy) I mikroproblematiki iz verkhnego severo-vostochnogo Kazakhstana [Inarticulate brachiopods and microproblematica from the Upper Cambrian of northeastern Kazakhstan]. In: Repina, L.N. (Ed.), Biostratigrafiya i paleontologiya kembriya Severnoj Azii. Trudy Institute Geologii i Geofiziki Akademii Nauk SSSR, Sibirskoe Otdelenie, vol. 765, pp. $158-170$.

Küppers, A.N., Pohler, S.M.L., 1992. Discovery of the first Early Ordovician conodonts from the Montagne Noire, southern France. In: Webby, B.D., Laurie, J.R. (Eds.), Global Perspectives on Ordovician Geology. Balkema, Rotterdam, pp. 487-494.

Kushan, B., 1973. Stratigraphie und Trilobitenfauna in der MilaFormation (Mittelkambriums-Tremadoc) im Alborz-Gebirge (NIran). Palaeontographica. Abteilung A, Paläozoologie, Stratigraphie $144,113-165$.

Landing, E., 2005. Early Paleozoic Avalon-Gondwana unity: an obituary-response to "Palaeontological evidence bearing on global Ordovician-Silurian continental reconstructions" by R.A. Fortey and L.R.M. Cocks. Earth-Science Reviews 69, 169-175.

Landing, E., Bowring, S.A., Davidek, K.L., Rushton, A.W.A., Fortey, R.A., Wimbledon, W.A.P., 2000. Cambrian-Ordovician boundary age and duration of the lowermost Ordovician Tremadoc Series based on $\mathrm{U}-\mathrm{Pb}$ zircon dates from Avalonian Wales. Geological Magazine 137, 485-494.

Ledru, P., Autran, A., Santallier, D., 1994. Lithostratigraphy of Variscan terranes in the French Massif Central: a basis for paleogeographical reconstruction. In: Keppie, J.D. (Ed.), Pre-Mesozoic Geology in France and Related Areas. Springer-Verlag, Berlin, pp. 276-288.

Legg, I.C., 1985. Trace fossils from a Middle Cambrian deltaic sequence, North Spain. In: Curran, H.A. (Ed.), Biogenic Structures: Their Use in Interpreting Depositional Environments. SEPM, Special Publication, vol. 35, pp. 151-165.

Lindström, M., 1955. Conodonts from the lowermost Ordovician strata of south-central Sweden. Geologiska Föreningens i Stockholm Förhandlingar 76, 517-604.

Loeschke, J., Zeider, N., 1982. Early Palaeozoic sills in the Cantabrian Mountains (Spain) and their geotectonic environment. Neues Jahrbuch für Geologie und Paläontologie, Abhandlungen 163, 419-439.

Löfgren, A., 1997. Conodont faunas from the upper Tremadoc at Brattefors, south-central Sweden, and reconstruction of the Palto$d u s$ apparatus. Geologiska Föreningens i Stockholm Förhandlingar 119, 257-266.

Loi, A., Pillola, G.L., Leone, F., 1995. The Cambrian and Early Ordovician of southwestern Sardinia. In: Cherchi, A. (Ed.),
Sardinia 95, 6th Paleobenthos International Symposium, Guidebook. Rendiconti del Seminario della Facoltà di Scienze dell'Università di Cagliari, vol. 65, pp. 63-81 (Supplement).

Loi, A., Pillola, G.L., Leone, F., 1996. La limite Cambrien-Ordovicien dans le SW de la Sardaigne: relations avec des événements eustatiques globaux. Comptes Rendus de l'Académie des Sciences ( $2^{\mathrm{e}}$ Série) $323,881-888$.

Lotze, F., 1961. Das Kambrium Spaniens. Teil 1: Stratigraphie. Akademie der Wissenschaften und der Literatur. Abhandlungen der Mathematisch-Naturwissenschaftlichen Klasse (6), 1-498.

Ludvigsen, R., Westrop, S.R., 1985. Three new Upper Cambrian stages for North America. Geology 13, 139-143.

Majeste-Menjoulas, C., Debat, J., 1994. Pyrenees. In: Keppie, J.P. (Ed.), Pre-Mesozoic Geology in France and Related Areas. Springer-Verlag, Berlin, pp. 442-457.

Marcos, A., Pérez-Estaún, A., Pulgar, J.A., Bastida, F., Aller, J., García-Alcalde, J.L., Sánchez de Posada, L.C., Truyols, J., Arbizu, M., García-López, S., Martínez Chacón, M.L., Méndez Bedia, I., Méndez-Fernández, C., Menéndez, J.R., Soto, F., Truyols-Massoni, M., Villa, E., Lorenzo, P., Rodríguez Fernández, L.R., 1982. Mapa Geológico de España E 1:50 000. Hoja no 77 (La Plaza). IGME, Madrid.

Marini, F., 1988. "Phase" sarde et distension du domaine SudVarisque, effects de point chaud? Une hypothèse fondée sur les données nouvelles du volcanisme albigeois. Comptes Rendus de l'Académie des Sciences ( $2^{\mathrm{e}}$ Série) 306, 443-450.

Martin, F., 1972. Les Acritarches de l'Ordovicien inférieur de la Montagne Noire (Hérault, France). Bulletin de l'Institute Royal des Sciences Naturelles de la Belgique, Sciences de la Terre, vol. 48, pp. 1-61.

Martin, F., Dean, W.T., 1981. Middle and Upper Cambrian and Lower Ordovician acritarchs from Random Island, Eastern Newfoundland. Geological Survey of Canada Bulletin 343, 1-43.

McGowran, B., Li, Q., Moss, G., 1997. The Cenozoic neritic record in southern Australia: the biogeohistorical framework. In: James, N.P., Clarke, A.D. (Eds.), Cool-Water Carbonates. Special Publication, vol. 56. SEPM, pp. 185-203.

McKerrow, W.S., Scotese, C.R., Brasier, M.D., 1992. Early Cambrian continental reconstructions. Journal of the Geological Society, London 149, 599-606.

Michard, A., 1976. Eléments de géologie marocaine. Notes et Mémoires du Service Géologique du Maroc 252, 1-408.

Montañez, I.P., Banner, J.L., Osleger, D.A., Borg, L.E., Bosserman, P.J., 1996. Integrated $\mathrm{Sr}$ isotope variations and sea-level history of Middle to Upper Cambrian platform carbonates: implications for the evolution of Cambrian seawater ${ }^{87} \mathrm{Sr} /{ }^{86} \mathrm{Sr}$. Geology 24, 917-920.

Murphy, J.B., Gutiérrez-Alonso, G., Nance, R.D., Fernández-Suárez, J., Keppie, J.D., Quesada, C., Strachon, R.A., Dostal, J., 2006. Origin of the Rheic Ocean: rifting along a Neoproterozoic suture? Geology 34, 325-328.

Nicholson, H.A., 1868. The graptolites of the Skiddaw Series. Quarterly Journal of the Geological Society, London 24, 125-145.

Nicoll, R.S., Laurie, J.R., Shergold, J.H., 1992. Preliminary correlation of latest Cambrian to Early Ordovician sea level events in Australia and Scandinavia. In: Webby, B.D., Laurie, J. R. (Eds.), Global Perspectives on Ordovician Geology. Balkema, Rotterdam, pp. 381-393.

Nysæther, E., Torsvik, T.H., Feist, R., Walderhang, H.J., Eide, E.A., 2002. Ordovician palaeogeography with new palaeomagnetic data from the Montagne Noire (Southern France). Earth and Planetary Science Letters 203, 329-341. 
Ortega, G., Albanesi, G.L., 2005. Tremadocian Graptolite-Conodont Biostratigraphy of the South American Gondwanan margin (Eastern Cordillera, NW Argentina). Geologica Acta 3, 355-371.

Osleger, D.A., Read, J.F., 1993. Comparative analysis of methods used to define eustatic variations in outcrop: Late Cambrian interbasinal sequence development. American Journal of Science 293, $157-216$

Özgül, N., Gedik, I., 1973. New data on the stratigraphy and conodont faunas of the Çaltepe Limestone and Seydișehir Formation Lower Palaeozoic of the central Taurus Range. Bulletin of the Geological Society of Turkey $16,39-52$.

Palacios, T., 1997. Acritarcos del Cámbrico Superior de Borobia, Soria: implicaciones bioestratigráficas. Libro Resúmenes y Excursiones, XIII Jornadas de Paleontología y V Reunión Internacional del Proyecto IGCP no. 351. A Coruña, pp. 90-91.

Palmer, A.R., 1981. Subdivision of the Sauk Sequence. In: Taylor, M.E. (Ed.), Short Papers for the Second International Symposium on the Cambrian System. US Geological Survey Open-file Report, vol. 81-743, pp. 160-162.

Palmer, A.R., 1998. A proposed nomenclature for stages and series for the Cambrian of Laurentia. Canadian Journal of Earth Sciences 35, $323-328$

Paris, F., Robardet, M., Dabard, M.P., Ghienne, J.F., Guillocheau, F., Le Hérissé, A., Loi, A., Mélou, M., Feist, R., Servais, T., Shergold, J., Vidal, M., Vizcaïno, D., 1999. Ordovician sedimentary rocks of France. Acta Universitatis Carolinae, Geologica 43, 85-88.

Parsons, M.G., Anderson, M.M., 2000. Acritarch microfloral succession from the Late Cambrian and Ordovician (early Tremadoc) of Random Island, Eastern Newfoundland, and its comparison to coeval microfloras, particularly those of the Eastern European Platform. American Association of Stratigraphic Palynologists Foundation Contribution Series, College Station, vol. 38, pp. 1-123.

Peng, Shanchi, Robison, R.A., 2000. Agnostoid biostratigraphy across the Middle-Upper Cambrian boundary in Hunan, China. Paleontological Society Memoir 53, 1-104.

Peng, Shanchi, Babcock, L.E., 2001. Cambrian of the Hunan-Guizhou region, South China. In: Peng, Shanchi, Babcock, L.E., Zhu, Maoyan (Eds.), Cambrian System of South China. Press of University of Science and Technology of China, Hefei, pp. 3-51.

Peng, Shanchi, Geyer, G., Hamdi, E., 1999. Trilobites from the Shahmirzad section, Alborz Mountains, Iran: their taxonomy, biostratigraphy and bearing for international correlation. Beringeria $25,3-66$.

Peng, Shanchi, Babcock, L.E., Lin, Huanling, Chen, Yongan, Zhu, Xuejian, 2001a. Potential global stratotype section and point for the base of an Upper Cambrian series defined by the first appearance of the trilobite Glyptagnostus reticulatus, Hunan Province, China. Acta Palaeontologica Sinica 40, 157-172 (Supplement).

Peng, Shanchi, Babcock, L.E., Lin, Huanling, 2001b. Illustrations of polymeroid trilobites from the Huaqiao Formation (Middle-Upper Cambrian), Paibi and Wangcun sections, northwestern Hunan, China. In: Peng, Shanchi, Babcock, L.E., Zhu, Maoyan (Eds.), Cambrian System of South China. Press of University of Science and Technology of China, Hefei, pp. 99-122.

Peng, Shanchi, Babcock, L.E., Lin, Huanling, 2004. Polymerid trilobites from the Cambrian of Northwestern Hunan, China. Volumes I and II. Science Press, Beijing. 333+355 pp.

Pillola, G.L., 1991. Occurrence of Proteuloma (Trilobita) in the Cabitza Formation (Cambro-Tremadoc, SW Sardinia, Italy): palaeobiogeographic implications. Geologia del Basamento Italiano (Convegno in memoria di Tommaso Cocozza, Siena), pp. 59-61.
Pillola, G.L., Gutiérrez-Marco, J.C., 1988. Graptolites du Tremadoc du sud-ouest de la Sardaigne (Italie): paléoécologie et contexte tectono-sédimentaire. Geobios 21, 553-565.

Pillola, G.L., Leone, F., 1993. Biostratigraphical and sedimentological data from the Cabitza Formation (Middle Cambrian-Tremadoc, SW Sardinia, Italy): palaeogeography and Cambrian-Ordovician boundary. IGCP, vol. 319. Liverpool, Abstracts, 22.

Pillola, G.L., Piras, S., Serpagli, E., in press. Upper Tremadoc-Lower Arenig? Anisograptid-Dichograptid fauna from the Cabitza Formation (Lower Ordovician, SW Sardinia, Italy). Revue de Micropaléontologie.

Popov, L.E., Holmer, L.E., 1994. Cambrian-Ordovician lingulate brachiopods from Scandinavia, Kazahkstan, and South Ural Mountains. Fossils and Strata 35, 1-156.

Popov, L.E., Ushatinskaya, G.T., 1992. Lingulidy, proizkhozhdenie discinid, sistematika vysokikh taksonov [Lingulids, the origin of discinids and systematics of higher taxa]. In: Repina, L.N., Rozanov, A.U. (Eds.), Drevnejshie brakhiopody territorii Severnoi Evrazii, Novosibirsk, pp. 59-67.

Popov, L.E., Vinn, O., Nikitina, O.I., 2001. Brachiopods of the redefined family Tritoechiidae from the Ordovician of Kazakhstan and South Urals. Geobios 32, 131-155.

Prigmore, J.K., Butler, A.J., Woodcock, N.H., 1997. Rifting during separation of Eastern Avalonia from Gondwana: evidence from subsidence analysis. Geology 25, 203-206.

Ribecai, C., Bagnoli, G., Mazzarini, F., Musumeci, G., 2005. Paleontological evidence for Late Cambrian in the Arburese area, SW Sardinia. Carnets de Géologie (2), 45-50.

Robson, S.P., Pratt, B.R., 2001. Cambrian and Ordovician linguliform brachiopods from the Shallow Bay Formation (Cow Head Group), western Newfoundland. Journal of Paleontology 75, 241-260.

Robson, S.P., Nowlan, G.S., Pratt, B.R., 2003. Middle to Upper Cambrian linguliformean brachiopods from the Deadwood Formation of subsurface Alberta and Saskatchewan, Canada. Journal of Paleontology 77, 201-211.

Rowell, A.J., Brady, M.J., 1976. Brachiopods and biomeres. Brigham Young University Geology Studies 23, 165-180.

Rowell, A.J., Henderson, R.A., 1978. New genera of acrotretids from the Cambrian of Australia and United States. The University of Kansas, Paleontological Contributions 93, 1-12.

Rowland, S.M., Shapiro, R.S., 2002. Reef patterns and environmental influences in the Cambrian and earliest Ordovician. SEPM Special Publication, vol. 72, pp. 95-128.

Rushton, A.W.A., 1983. Trilobites from the Upper Cambrian Olenus Zone in central England. In: Briggs, D.E.G., Lane, P.D. (Eds.), Trilobites and Other Early Arthropods, Papers in Honour of Professor H.B. Whittington, F.R.S. Special Papers in Palaeontology, vol. 30, pp. 107-139.

Rushton, A.W.A., Hughes, N.C., 1996. Biometry, systematics and biogeography of the Late Cambrian trilobite Maladioidella abdita. Transactions of the Royal Society of Edinburgh: Earth Sciences $86,247-256$.

Saltzman, M.R., Runnegar, B., Lohmann, K.C., 1998. Carbon isotope stratigraphy of Upper Cambrian (Steptoean Stage) sequences of the eastern Great Basin: record of a global oceanographic event. Geological Society of America Bulletin 110, 285-297.

Saltzman, M.R., Ripperdan, R.L., Brasier, M.D., Lohman, K.C., Robison, R.A., Chang, W.T., Shanchi, Peng, Ergaliev, G.K., Runnegar, B., 2000. A global carbon isotope excursion (SPICE) during the Late Cambrian: relation to trilobite extinctions, organicmatter burial and sea level. Palaeogeography, Palaeoclimatology, Palaeoecology 162, 211-223. 
Sánchez-García, T., Bellido, F., Quesada, C., 2003. Geodynamic setting and geochemical signatures of Cambrian-Ordovician rift-related igneous rocks (Ossa-Morena Zone, SW Iberia). Tectonophysics 365, 233-255.

Schmitz, U., 1971. Stratigraphie und Sedimentologie im Kambrium und Tremadoc der Westlichen Iberischen Ketten nördlich Ateca. Münster. Münstersche Forschungen zur Geologie und Paläontologie 22, $1-123$.

Sdzuy, K., 1955. Cystoideen aus den Leimitz-Schiefern (Tremadoc). Senckenbergiana Lethaea 35, 269-276.

Sdzuy, K., 1958. Fossilien aus dem Tremadoc der Montagne Noire. Senckenbergiana Lethaea 39, 255-285.

Sdzuy, K., 1972. Das Kambrium der acadobaltischen Fauneprovinz. Gegenwärtiger Kenntnisstand und Probleme. Zentralblat für Geologie und Paläontologie 2 (1-2), 1-91.

Seilacher, A., 1970. Cruziana-stratigraphy of "non-fossiliferous" Paleozoic sandstones. In: Crimes, P., Harper, D. (Eds.), Trace Fossils. Geological Journal, Special Issue, vol. 3, pp. 447-476.

Seilacher, A., MacClintock, C., 2005. Crinoid anchoring strategies for soft-bottom dwelling. Palaios 20, 224-240.

Serpagli, E., Ferretti, A., Leone, F., Loi, A., Pillola, G.L., 1998. Conodonts of the Late Cambrian sections near Villamassargia. In: Serpagli, E. (Ed.), Sardinia Guide-book, ECOS VII. Giornale di Geologia, vol. 60, pp. 138-143. Special Issue.

Serpagli, E., Ferretti, A., Vizcaïno, D., Álvaro, J.J., 2007. A new Early Ordovician conodont genus from the southern Montagne Noire, France. Palaeontology 50.

Shergold, J.H., 1982. Idamean (Late Cambrian) trilobites, Burke River structural belt, western Queensland. Bureau of Mineral Resources Geology and Geophysics of Australia Bulletin 187, 1-69.

Shergold, J.H., Sdzuy, K., 1984. Cambrian and Early Tremadocian trilobites from Sultan Dağ, central Turkey. Senckenbergiana Lethaea 65, 51-135.

Shergold, J.H., Sdzuy, K., 1991. Late Cambrian trilobites from the Iberian Mountains, Zaragoza Province, Spain. Beringeria 4, 193-235.

Shergold, J.H., Geyer, G., 2001. The International Subcommission on Cambrian Stratigraphy: Progress Report 2001. Acta Palaeontologica Sinica 40, 1-3 (Supplement).

Shergold, J.H., Liñán, E., Palacios, T., 1983. Late Cambrian trilobites from the Najerilla Formation, north-eastern Spain. Palaeontology 26, 71-92.

Shergold, J.H., Bordonaro, O., Liñán, E., 1995. Late Cambrian agnostoid trilobites from Argentina. Palaeontology 38, 241-257.

Shergold, J.H., Feist, R., Vizcaïno, D., 2000. Early Late Cambrian trilobites of Australo-Sinian aspect from the Montagne Noire, southern France. Palaeontology 43, 599-632.

Solovjev, I.A., Popov, L.E., Samsonov, V.V., 1984. Novye dannye o verkhnekembriiskoi faune gor Elsuert i Pensakola (zapadnaia Antarktida) [New data on the Upper Cambrian Fauna of Ellsworth and Pensacola Mountains, West Antarctica]. Antarktica 23, 46-71.

Stampfli, G.H., Von Raumer, J.F., Borel, G.D., 2002. Paleozoic evolution of pre-Variscan terranes: from Gondwana to the Variscan collision. In: Martínez Catalán, J.R., Hatcher, R.D., Arenas, R., Díaz García, F. (Eds.), Variscan-Appalachian Dynamics: the Building of a Late Paleozoic Basement. Geological Society of America, Special Papers, vol. 364, pp. 263-280.

Stille, M., 1939. Bemerkungen betreffend die 'sardische' Faltung und den Ausdruck 'ophiolothisch'. Zeitschrift der Deutschen Gesellschaft 91, 771-773.

Sturesson, U., Popov, L.E., Holmer, L.E., Bassett, M.G., Felitsyn, S., Belyatski, B., 2005. Neodymium isotopic composition of Cambrian-Ordovician biogenic apatite in the Baltoscandian
Basin: implications for palaeogeographic evolution and patterns of biodiversity. Geological Magazine 142, 419-439.

Szaniawski, H., 1980. Conodonts from the Tremadocian Chalcedony Beds, Holy Cross Mountains (Poland). Acta Palaeontologica Polonica 25, 101-121.

Torsvik, T.H., Rehnström, E.F., 2001. Cambrian palaeomagnetic data from Baltica: implications for true polar wander and Cambrian palaeogeography. Journal of the Geological Society, London 158, 321-330.

Tortello, M.F., Vizcaïno, D., Álvaro, J.J., 2006. Early Ordovician agnostoid trilobites from the southern Montagne Noire, France. Journal of Paleontology 80, 477-495.

Ubaghs, G., 1998. Echinodermes nouveaux du Cambrien supérieur de la Montagne Noire (France méridionale). Geobios 31, 809-829.

Valverde-Vaquero, P., Dunning, G.R., 2000. New U-Pb ages for Early Ordovician magmatism in Central Spain. Journal of the Geological Society, London 157, 15-26.

Van Carlsteren, P.W.C., Den Tex, E., 1978. An Early Paleozoic continental rift system in Galicia (NW Spain). In: Ramberg, I.B., Neumann, E.R. (Eds.), Tectonics and Geophysics of Continental Rifts. D. Reidel Publishing Company, Dordrecht, pp. $125-132$.

Van den Bosch, W.J., 1969. Geology of the Luna-Sil region, Cantabrian Mountains (NW Spain). Leidse Geologische Mededelingen 44, 137-225.

Van der Meer Mohr, C.G., Kuiper, R.P., Van Carlsteren, P.W.C., Den Tex, E., 1981. The Hesperian Massif: from Iapetus aulacogen to ensialic orogen. A model for its development. Geologische Rundschau 70, 459-472.

Vanguestaine, M., 1978. Critères palynostratigraphiques conduisant a la reconnaissance d'un pil couche Revinien dans le sondage de Grand-Halleux. Annales de la Société Géologique de Belgique 100, 249-276.

Vanguestaine, M., Aramburu, C., 1988. Cambrian and Ordovician acritarchs and Chitinozoa from the Cantabrian Mountains, NW Spain. Preliminary results. International Symposium on CircumMediterranean Palynology, April 1988, Zeist, Netherlands. Abstracts.

Vanguestaine, M., Van Looy, J., 1983. Acritarches du Cambrien moyen de la vallée de Tacheddirt (Haut-Atlas, Maroc) dans le cadre d'une nouvelle zonation du Cambrien. Annales de la Société Géologique de Belgique 106, 69-85.

Viira, V., 1970. Konodonty Varanguskoj pachki (Verchnij Tremadok Estonii) [Conodonts of the Varangu Member (Estonian Upper Tremadoc)]. Eesti NSV Teaduste Academia, Keemia-Geoloogia 19, 224-233.

Villas, E., Arbizu, M., Bernárdez, E., Méndez-Bedia, I., Aramburu, C., 1995. Protambonites primigenius (Brachiopoda, Clitambonitidina) y el límite Cámbrico-Ordovícico en la Serie de los Cabos (Zona Asturoccidental-Leonesa, NO de España). Revista Española de Paleontología 10, 140-150.

Vizcaïno, D., Álvaro, J.J., 2003. Adequacy of the Lower Ordovician trilobite record in the southern Montagne Noire (France): biases for biodiversity documentation. Transactions of the Royal Society of Edinburgh: Earth Sciences 93, 1-9 (for 2002).

Wolf, R., 1980. The lower and upper boundary of the Ordovician system of some selected regions (Celtiberia, Eastern Sierra Morena) in Spain. Neues Jahrbuch für Geologie und Paläontologie, Abhandlungen 160, 118-137.

Wolfart, R., 1974. Die Fauna (Brachiopoda, Mollusca, Trilobita) des älteren Ober-Kambriums (Ober-Kushanian) von Dorah Shah Dad, Südost-Iran, und Surkh Bumm, Zentral Afghanistan. Geologische Jahrbuch 8, 71-184. 
Yang, Jialu, Xu, Shiqiu, 1997. The second-order sequence division and sea level fluctuation in Cambrian on the border of Sichuan, Guizhou and Hunan. Earth Science-Journal of China University of Geosciences 22, 466-470 (in Chinese with English summary).

Zeballo, F.J., Albanesi, G.L., Ortega, G., 2005. Conodontes y graptolitos de la formaciones Alfacito y Rupasca (Tremadociano) en el área de Alfacito, Tilcra, Cordillera Oriental de Jujuy, Argentina. Parte 1: Bioestratigrafia, Ameghiniana 42, 39-46.

Zell, M.G., Rowell, A.J., 1988. Brachiopods of the Holm Dal Formation (late Middle Cambrian), central North Greenland. In: Peel, J.S. (Ed.), Stratigraphy and Palaeontology of the Holm Dal
Formation (late Middle Cambrian), central North Greenland. Meddelelser om Grønland, Geoscience, vol. 20, pp. 119-244.

Zhang, Wentang, Jell, P.A., 1987. Cambrian Trilobites of North China: Chinese Cambrian Trilobites Housed in the Smithsonian Institution. Science Press, Beijing, pp. 1-459.

Zhang, Yuandong, Erdtmann, B.-D., Feng, Hongzhen, 2004. Tremadocian (Early Ordovician) graptolite biostratigraphy in China. Newsletters on Stratigraphy 40, 155-182.

Żylińska, A., 2001. Late Cambrian trilobites from the Holy Cross Mountains, central Poland. Acta Geologica Polonica 51, 333-383. 